ARTICLE

\title{
Dinucleoside polyphosphates act as 5'-RNA caps in bacteria
}

Oldřich Hudeček ${ }^{1,3}$, Roberto Benoni ${ }^{1,3}$, Paul E. Reyes-Gutierrez ${ }^{1}$, Martin Culka (D) ${ }^{1}$, Hana Šanderová2 Martin Hubálek ${ }^{1}$, Lubomír Rulíšek (iD) ${ }^{1}$, Josef Cvačka (iD) ${ }^{1}$, Libor Krásný (i) ${ }^{2}$ \& Hana Cahová (D) ${ }^{1 凶}$

It has been more than 50 years since the discovery of dinucleoside polyphosphates $\left(\mathrm{Np}_{n} \mathrm{Ns}\right)$ and yet their roles and mechanisms of action remain unclear. Here, we show that both methylated and non-methylated $\mathrm{Np}_{n} \mathrm{Ns}$ serve as RNA caps in Escherichia coli. $\mathrm{Np}_{n} \mathrm{Ns}$ are excellent substrates for T7 and E. coli RNA polymerases (RNAPs) and efficiently initiate transcription. We demonstrate, that the E. coli enzymes RNA 5'-pyrophosphohydrolase $(\mathrm{RppH})$ and bis(5'-nucleosyl)-tetraphosphatase $(\mathrm{ApaH})$ are able to remove the $\mathrm{Np}_{n} \mathrm{~N}$-caps from RNA. ApaH is able to cleave all $\mathrm{Np}_{n} \mathrm{~N}$-caps, while $\mathrm{RppH}$ is unable to cleave the methylated forms suggesting that the methylation adds an additional layer to RNA stability regulation. Our work introduces a different perspective on the chemical structure of RNA in prokaryotes and on the role of RNA caps. We bring evidence that small molecules, such as $\mathrm{Np}_{n} \mathrm{Ns}$ are incorporated into RNA and may thus influence the cellular metabolism and RNA turnover.

\footnotetext{
${ }^{1}$ Institute of Organic Chemistry and Biochemistry of the Czech Academy of Sciences, Flemingovo nam. 2, 16610, Prague 6, Czech Republic. ${ }^{2}$ Institute of Microbiology of the Czech Academy of Sciences, Vídeňská 1083, 142 20, Prague, Czech Republic. ${ }^{3}$ These authors contributed equally: Oldřich Hudeček,




T he role and chemical structure of the $5^{\prime}$-end of prokaryotic RNA is still unclear. The discovery of nicotinamide adenine dinucleotide $(\mathrm{NAD})^{1,2}$ and coenzyme $\mathrm{A}(\mathrm{CoA})^{3} 5^{\prime}$ RNA caps changed the perception of the RNA structure. $5^{\prime}$-caps are usually cleaved by NudiX enzymes ${ }^{4}$ (NudC (refs. ${ }^{1,5,6}$ ), RNA $5^{\prime}$-pyrophosphohydrolase $(\mathrm{RppH})^{7,8}$ ), which can, besides their decapping role (eukaryotic Nudt16 and Dcp2 (refs. $\left.{ }^{9,10}\right)$ ), also cleave nucleoside diphosphates linked to another moiety (e.g., dinucleoside polyphosphates $\left.\left(\mathrm{Np}_{n} \mathrm{Ns}\right)^{11,12}\right) . \mathrm{Np}_{n} \mathrm{Ns}$ are ubiquitous molecules ${ }^{13-15}$ present in both prokaryotic and eukaryotic organisms.Their intracellular concentrations can increase from the $\mu \mathrm{M}$ to the $\mathrm{mM}$ range under stress conditions ${ }^{11,16}$, which is why they are often called alarmones. Nevertheless, the molecular targets of the alarm signaled by $\mathrm{Np}_{n} \mathrm{Ns}$ have not been identified yet. The main source of the $\mathrm{Np}_{n} \mathrm{Ns}$ is the back reaction of an aminoacyl adenylate with an acceptor nucleotide catalyzed by various aminoacyl-tRNA synthetases ${ }^{17}$. But there is evidence that e.g., the ubiquitinylation process can lead to $A_{4} A$ or $A p_{3} A$ (ref. ${ }^{18}$ ). Even though they have a similar chemical structure to known RNA caps, such as NAD (refs. ${ }^{1,19,20}$ ) and the 7methylguanylate $\mathrm{cap}^{21}$, they were never detected as a part of RNA.

In this work, we show that $\mathrm{Np}_{n} \mathrm{Ns}$ can be accepted by two types of RNA polymerases (RNAPs; bacteriophage T7 and E. coli) as non-canonical initiating nucleotides (NCINs) in in vitro transcription. To prove the existence of $\mathrm{Np}_{n} \mathrm{~N}-\mathrm{RNA}$ caps in vivo, we develop an liquid chromatography-mass spectrometry (LC-MS) technique for the detection of $\mathrm{Np}_{n} \mathrm{Ns}$ in isolated and digested RNA. We detect six previously unknown $\mathrm{Np}_{n} \mathrm{~N}$-caps $\left(\mathrm{Ap}_{3} \mathrm{~A}\right.$, $\mathrm{m}^{6} \mathrm{Ap}_{3} \mathrm{~A}, \mathrm{Ap}_{3} \mathrm{G}, \mathrm{m}^{7} \mathrm{Gp}_{4} \mathrm{Gm}, \mathrm{Ap}_{5} \mathrm{~A}$, and $\mathrm{mAp} \mathrm{p}_{5} \mathrm{G}$ ) in fractions of short RNA (sRNA) from Escherichia coli harvested in exponential phase and additional three $\mathrm{Np}_{n} \mathrm{~N}$-caps $\left(\mathrm{mAp}_{4} \mathrm{G}, \mathrm{mAp}_{5} \mathrm{~A}\right.$, and $2 \mathrm{mAp} \mathrm{p}_{5} \mathrm{G}$ ) in late stationary phase. Some of the detected $\mathrm{Np}_{n} \mathrm{~N}$ caps are mono- or dimethylated. We identify two enzymes, RppH from the NudiX family and bis(5'-nucleosyl)-tetraphosphatase $(\mathrm{ApaH})$, as decapping enzymes that can cleave $\mathrm{Np}_{n} \mathrm{~N}-\mathrm{RNA}$. While the methylations of $\mathrm{Np}_{n} \mathrm{~N}$-caps protect the RNA from decapping by RppH, ApaH cleaves even the methylated forms of $\mathrm{Np}_{n} \mathrm{~N}$-caps. We propose that bacteria use methylated caps as protection against RNA degradation under starvation conditions.

\section{Results}

In vitro incorporation of $\mathrm{Np}_{\boldsymbol{n}} \mathrm{Ns}$ into RNA. To investigate whether $\mathrm{Np}_{n} \mathrm{Ns}$ (Fig. 1a) can serve as NCINs similarly to NAD and $\mathrm{CoA}$ (ref. ${ }^{22}$ ), we performed in vitro transcriptions in the presence of different $\mathrm{Np}_{n} \mathrm{Ns}\left(\mathrm{Ap}_{3-6} \mathrm{~A}, \mathrm{Ap}_{4-5} \mathrm{G}\right.$, and $\mathrm{Gp}_{4} \mathrm{G}$, Fig. $1 \mathrm{~b}$ ) with T7 RNAP (single peptide chain enzyme, derived from an $E$. coli-infecting phage) and E. coli RNAP (multi-subunit enzyme). T7 RNAP was selected as a first tool to explore the capability of $\mathrm{Np}_{n} \mathrm{Ns}$ to be substrates of RNAPs as it was previously shown to be able to use comparably sized non-canonical initiating substrates $^{23}$. Consistently, based on three-dimensional structures, the nucleotide-binding pockets for initiation phase of T7 (ref. ${ }^{24}$ ) and E. coli ${ }^{22}$ RNAP are spacious enough to accommodate such substrates.

The in vitro transcription produced a mixture of capped and uncapped RNA (step 1 in Fig. 1b, Supplementary Fig. 1a). The presence of the caps was confirmed by electrophoretic analysis after treatments with the $5^{\prime}$-polyphosphatase and the Terminator $^{\mathrm{TM}} 5^{\prime}$-phosphate-dependent exonuclease (terminator, steps 2 and 3 in Fig. 1b). The former enzyme dephosphorylated the $5^{\prime}-$ triphosphate RNA (5'-ppp RNA) but not the capped RNA. The terminator then digested all RNA with 5'-monophosphate termini (5'-p RNA) and left the capped RNA intact. We observed that all tested $\mathrm{Np}_{n} \mathrm{Ns}$ were excellent substrates for the T7 RNAP and served as NCINs for the in vitro transcription (Fig. 1c). The only enzymatic incorporation of an $\mathrm{Np}_{n} \mathrm{~N}$ into RNA that had been previously reported involved methylated derivates of $\mathrm{Gp}_{n} \mathrm{G}$ (diguanosines polyphosphates, eukaryotic cap variants) prepared for a translation inhibition study ${ }^{25}$.

To identify the best substrate for T7 RNAP under in vitro conditions, we varied the concentrations of the $\mathrm{Np}_{n} \mathrm{Ns}$ in the presence of constant $(1 \mathrm{mM})$ ATP and GTP concentrations (Fig. 1e, Supplementary Fig. 1c, d). The amount of capped RNA increased linearly with the concentration of $\mathrm{Np}_{n} \mathrm{Ns}$. When the ratio of ATP (GTP) to $\mathrm{Np}_{n} \mathrm{~N}$ was 1, we observed between $27 \%$ (for $\mathrm{Ap}_{6} \mathrm{~A}$ ) and $46 \%$ (for $\mathrm{Ap}_{4} \mathrm{G}$ ) of capped products. The NADcapped RNA was produced in a comparable amount to the majority of $\mathrm{Np}_{n} \mathrm{Ns}$. The similar behavior of $\mathrm{Np}_{n} \mathrm{Ns}$ to $\mathrm{NAD}$ supports the theory that these molecules might be present as $5^{\prime}$ RNA caps in cells.

Subsequently, we tested the E. coli RNAP that is known to accept NAD as an NCIN both in vitro and in vivo $22,26,27$ (Supplementary Fig. 1b). To confirm the existence of $5^{\prime}$-capped RNA products, we treated them with the $5^{\prime}$-polyphosphatase and the terminator. We used two different models of well characterized promoters ( $r r n B$ P1 and rnaI) for E. coli RNAP. In both cases, we observed a higher production of $\mathrm{Np}_{n} \mathrm{~N}$-RNA compared to NAD-RNA (Fig. 1d). Nevertheless, the promoter sequence may affect the efficiency of incorporation of $\mathrm{Np}_{n} \mathrm{Ns}$, the same way it influences the incorporation of NAD (ref. ${ }^{22}$ ).

LC-MS analysis of $\boldsymbol{E}$. coli sRNA. Next, we wanted to determine whether $\mathrm{Np}_{n} \mathrm{Ns}$ exist as $5^{\prime}$-RNA caps in vivo in E. coli. We established an LC-MS method for their detection in RNA. As the intracellular concentration of $\mathrm{Np}_{n} \mathrm{Ns}$ is known to grow under stress conditions ${ }^{11,16,28}$, we collected cells from exponential (EXP, $\mathrm{OD}=0.3$ ) and late stationary (STA) phases of growth. We focused on sRNA where the NAD-cap ${ }^{2}$ and the CoA-cap ${ }^{3}$ have also been detected. The purified sRNA was washed to remove all non-covalently interacting molecules and digested by Nuclease P1 into the form of nucleotides (Fig. 2a). The negative control samples, where the addition of Nuclease P1 was omitted, did not show any signals of nucleotides or $\mathrm{Np}_{n} \mathrm{Ns}$, which excluded the possibility of non-covalently bound contamination (Supplementary Figs. 2-4).

In all the digested sRNA, we observed signals of $\mathrm{Ap}_{3} \mathrm{~A}\left([\mathrm{M}-\mathrm{H}]^{-}\right.$ at $\mathrm{m} / z$ 755.077), $\mathrm{Ap}_{3} \mathrm{G}\left([\mathrm{M}-\mathrm{H}]^{-}\right.$at $\mathrm{m} / z$ 771.071), and $\mathrm{Ap}_{5} \mathrm{~A}$ $\left([\mathrm{M}-2 \mathrm{H}]^{2-}\right.$ at $\mathrm{m} / z$ 457.009; Supplementary Fig. 2a-c). We also observed strong signals of mono- and dimethylated forms of $\mathrm{Np}_{n} \mathrm{Ns}$, specifically methyl- $\mathrm{Ap}_{3} \mathrm{~A}\left([\mathrm{M}-\mathrm{H}]^{-}\right.$at $\mathrm{m} / z$ 769.077), dimethyl-Gp $\mathrm{G}_{4} \mathrm{G}\left([\mathrm{M}-2 \mathrm{H}]^{2-}\right.$ at $\left.\mathrm{m} / \mathrm{z} 447.017\right)$, and methyl-Ap $\mathrm{G}$ $\left([\mathrm{M}-2 \mathrm{H}]^{2-}\right.$ at $m / z$ 472.019; Supplementary Fig. 3a-c). Besides the previously mentioned caps, we detected signals of methyl- $\mathrm{Ap}_{4} \mathrm{G}$ $\left([\mathrm{M}-2 \mathrm{H}]^{2-}\right.$ at $\left.m / z 432.019\right)$, methyl-Ap $\mathrm{A}\left([\mathrm{M}-2 \mathrm{H}]^{2-}\right.$ at $\mathrm{m} / \mathrm{z}$ 463.992), and dimethyl-Ap ${ }_{5} \mathrm{G}\left([\mathrm{M}-2 \mathrm{H}]^{2-}\right.$ at $m / z$ 479.014; Fig. $2 \mathrm{~b}$, Supplementary Fig. 4a-c) in STA. We compared our detected $\mathrm{m} / \mathrm{z}$ signals with those reported by $\mathrm{Liu}^{2}$. The only similar $\mathrm{m} / z$ was 771.073 , which can correspond to the $[\mathrm{M}-\mathrm{H}]^{-}$of $\mathrm{Ap}_{3} \mathrm{G}$.

LC-MS structure confirmation. To validate the structure of the detected $\mathrm{Np}_{n} \mathrm{~N}$-caps, we grew $E$. coli in minimal media with the sole source of nitrogen from either ${ }^{14} \mathrm{NH}_{4} \mathrm{Cl}$ or ${ }^{15} \mathrm{NH}_{4} \mathrm{Cl}$. We detected only three $\mathrm{Np}_{n} \mathrm{~N}$-caps: methyl- $\mathrm{Ap}_{3} \mathrm{~A}, \mathrm{Ap}_{3} \mathrm{G}$, and dimethyl-Gp ${ }_{4} \mathrm{G}$ (Fig. 2c-f, Supplementary Fig. 5a-c), because this type of growth represents a different type of stress. This experiment confirmed the presence of ten nitrogen atoms in every detected molecule. To further verify the chemical structure of $\mathrm{Np}_{n} \mathrm{Ns}$, we compared the LC-MS properties of standard $\mathrm{Gp}_{4} \mathrm{G}$ with the isomeric $p_{3} G p G$. While half of the $p_{3} G p G$ was 
a

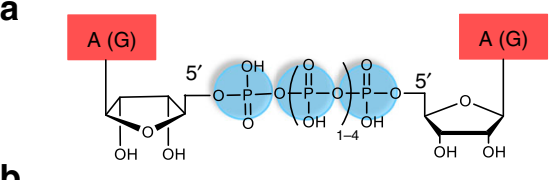

b

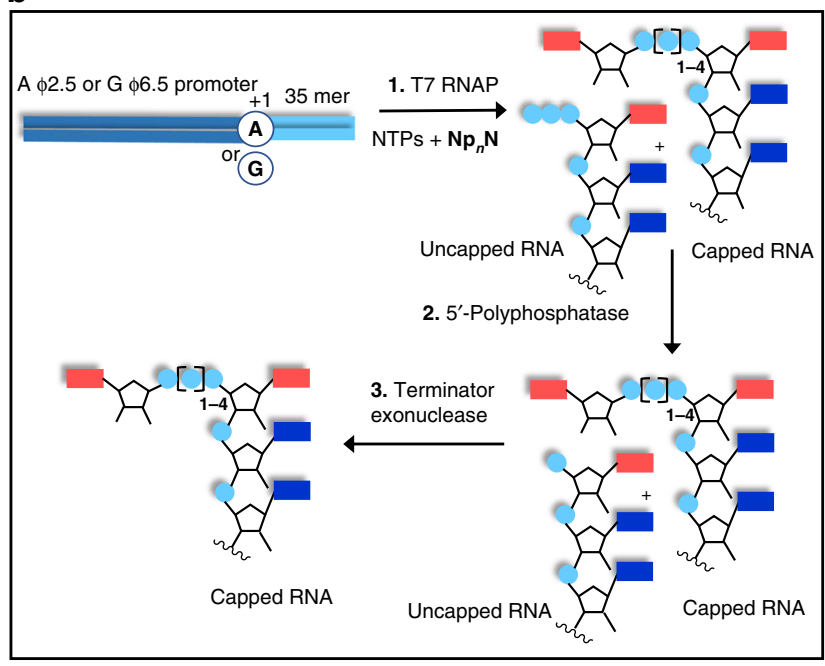

e

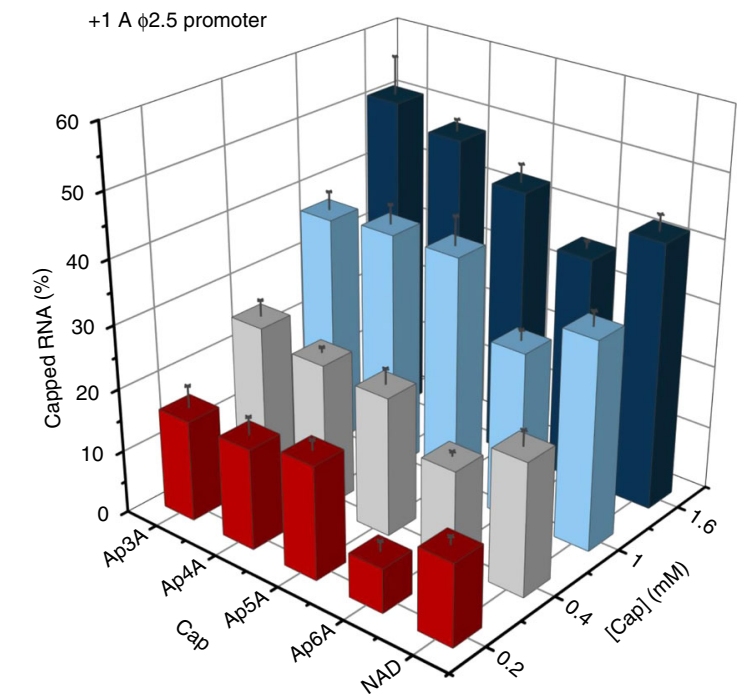

C
T7 RNAP
$+1$
A $\quad \phi 2.5$ CAGTAATACGACTCACTATTAGGG
G $\phi 6.5$ CAGTAATACGACTCACTATAGGGG
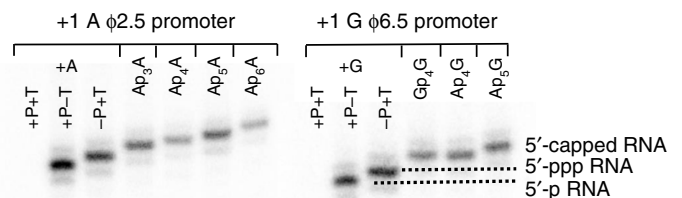

d

E. coli RNAP

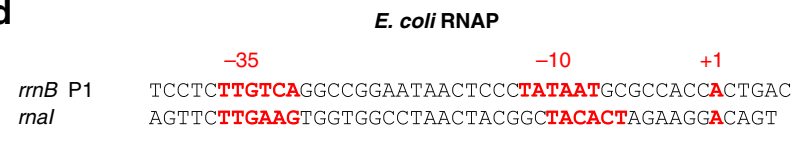

rnal


Fig. $1 \mathbf{N p} \mathbf{p}_{n} \mathbf{N s}$ are excellent substrates for RNAP. a The chemical structure of $\mathrm{Np}_{n} \mathrm{Ns}$. $\mathbf{b}$ Scheme of the in vitro transcription with RNAP in the presence of $\mathrm{Np}_{n} \mathrm{Ns}$ and template DNA yielding RNA starting with A or G. The first step resulted in a mixture of capped and uncapped RNAs, which was then treated by $5^{\prime}$-polyphosphatase (P). In the third step, the 5'-p RNA was degraded by terminator exonuclease (T). c Polyacrylamide gel electrophoretic (PAGE-12\%) analysis of the ( $\alpha-32$ P GTP labeled) in vitro transcription products ( $35 \mathrm{nt}$ ) with T7 RNAP followed by P and/or T treatment (all experiments were performed in triplicates). If not specified, samples were treated with both P and T. d PAGE analysis of the in vitro transcription products with E. coli RNAP, and two templates with promoter rrnB P1 and rnal, leading to A starting $144 \mathrm{nt}$ long RNA ( $r$ rnB P1) or 71 nt long RNA ( $r n a l$ ), followed by P and/or T treatment (all experiments were performed in triplicates). e Percentage of different types of capped RNA produced by in vitro transcription with T7 RNAP calculated from PAGE analysis. The depth axis represents various concentrations of $\mathrm{Np}_{n} \mathrm{Ns}(0.2$-red, 0.4 -gray, 1-light blue, and $1.6 \mathrm{mM}-$ dark blue) at a constant concentration of ATP $(1 \mathrm{mM})$ and GTP $(1 \mathrm{mM})$. The left panel shows the percentage of $A_{p_{3-6}} A$ and NAD-capped RNA, the right panel shows the percentage of $\mathrm{Ap}_{4-5} \mathrm{G}$ and $\mathrm{Gp}_{4} \mathrm{G}$. All experiments were performed in triplicates and calculated as average values. Error bars indicate standard deviations. Source data are provided in the Source Data file.

fragmented in the ionization source to $\mathrm{p}_{2} \mathrm{GpG}$, the $\mathrm{Gp}_{4} \mathrm{G}$ stayed intact (Supplementary Fig. 6a, b). The same behavior was observed for dimethyl- $\mathrm{Gp}_{4} \mathrm{G}$ in the E. coli RNA sample, proving the existence of the internal polyphosphate chain. By linear ion trap LC-MS, we detected an intact triphosphate chain of $\mathrm{Ap}_{3} \mathrm{~A}$ confirming its structure (Supplementary Fig. 7).

To identify the methylation positions, the synthetic standards of methylated $\mathrm{Np}_{n} \mathrm{Ns}$ are necessary to define their retention time and the best fragmentation conditions. As there are many possible methylation positions in the majority of detected methylated $\mathrm{Np}_{n} \mathrm{~N}$-caps making their synthesis extremely demanding, we focused on the characterization of $2 \mathrm{mGp}_{4} \mathrm{G}$ and $\mathrm{mAp}_{3} \mathrm{~A}$. The LC-MS analysis of $E$. coli sRNA confirmed the presence of one methyl group per one guanosine moiety in $2 \mathrm{mGp}_{4} \mathrm{G}$ (Supplementary Fig. 8). We hypothesized that these methylations could be in the positions $N^{7}\left(\mathrm{~m}^{7} \mathrm{G}\right)$ and $2^{\prime}-O(\mathrm{Gm})$ similarly to eukaryotic $\mathrm{m}^{7} \mathrm{Gp}_{3} \mathrm{Nm}$ RNA caps. We used customsynthesized $\mathrm{m}^{7} \mathrm{Gp}_{4} \mathrm{Gm}, \mathrm{m}^{1} \mathrm{Gp}_{4} \mathrm{Gm}$, and $\mathrm{m}^{2} \mathrm{Gp}_{4} \mathrm{Gm}$. In parallel, 
a

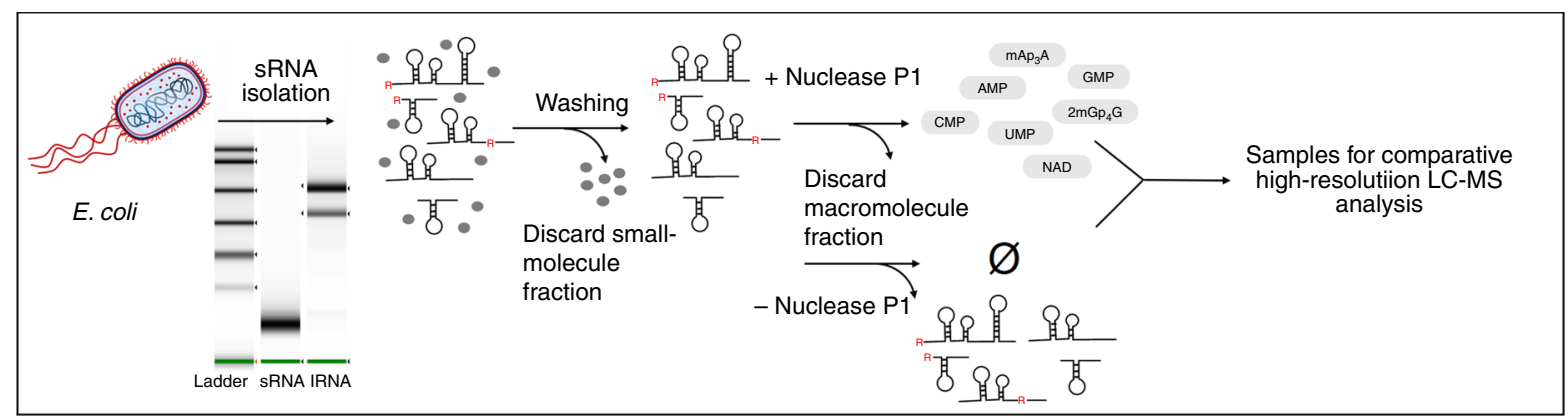

b

\begin{tabular}{|c|c|c|c|}
\hline \multirow[t]{2}{*}{ RNA cap } & \multirow{2}{*}{ Calculated mass } & \multicolumn{2}{|c|}{ Detected mass } \\
\hline & & EXP & STA \\
\hline $\mathrm{Ap}_{3} \mathrm{~A}$ & 755.074 & $755.077 \pm 0.001$ & $755.078 \pm 0.007$ \\
\hline $\mathrm{mAp}_{3} \mathrm{~A}$ & 769.090 & $769.080 \pm 0.006$ & $769.078 \pm 0.010$ \\
\hline $\mathrm{Ap}_{3} \mathrm{G}$ & 771.069 & $771.065 \pm 0.001$ & $771.060 \pm 0.010$ \\
\hline $\mathrm{mAp}_{4} \mathrm{G}$ & $432.022^{\mathrm{a}}$ & n.d. & $432.016 \pm 0.004^{a}$ \\
\hline $2 \mathrm{mGp}_{4} \mathrm{G}$ & $447.027^{\mathrm{a}}$ & $447.018 \pm 0.001^{a}$ & $447.021 \pm 0.005^{a}$ \\
\hline $\mathrm{Ap}_{5} \mathrm{~A}$ & $457.000^{\mathrm{a}}$ & $457.008 \pm 0.003$ & $457.000 \pm 0.013^{\mathrm{a}}$ \\
\hline $\operatorname{mAp}_{5} A$ & $464.007^{\mathrm{a}}$ & n.d. & $463.992 \pm 0.004^{a}$ \\
\hline $\mathrm{mAp}_{5} \mathrm{G}$ & $472.005^{\mathrm{a}}$ & $472.018 \pm 0.001^{a}$ & $472.020 \pm 0.002^{\mathrm{a}}$ \\
\hline $2 \mathrm{mAp}_{5} \mathrm{G}$ & $479.013^{\mathrm{a}}$ & n.d. & $479.003 \pm 0.010^{a}$ \\
\hline
\end{tabular}

C

\begin{tabular}{ccccc} 
RNA cap & $\begin{array}{c}{ }^{14} \mathrm{~N} \text { calculated } \\
\text { mass }\end{array}$ & $\begin{array}{c}{ }^{15} \mathrm{~N} \text { calculated } \\
\text { mass }\end{array}$ & ${ }^{14} \mathrm{~N}$ detected mass & ${ }^{15} \mathrm{~N}$ detected mass \\
\hline $\mathrm{mAp}_{3} \mathrm{~A}$ & 769.090 & 779.06 & $\mathbf{7 6 9 . 0 8 5} \pm \mathbf{0 . 0 1 1}$ & $\mathbf{7 7 9 . 0 5 6 \pm 0 . 0 0 1}$ \\
\hline $\mathrm{Ap}_{3} \mathrm{G}$ & 771.069 & 781.039 & $\mathbf{7 7 1 . 0 6 9 \pm 0 . 0 0 6}$ & $\mathbf{7 8 1 . 0 3 5 \pm 0 . 0 1 3}$ \\
\hline $2 \mathrm{mGp}_{3} \mathrm{G}$ & $447.027^{\mathrm{a}}$ & 452.012 & $\mathbf{4 4 7 . 0 2 0 \pm 0 . 0 0 1}$ & $\mathbf{4 5 2 . 0 0 5 \pm 0 . 0 0 1}$
\end{tabular}

d

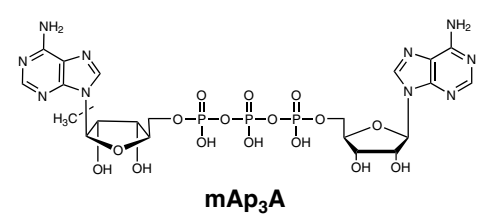

e

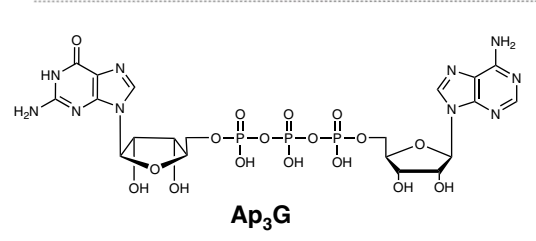

f

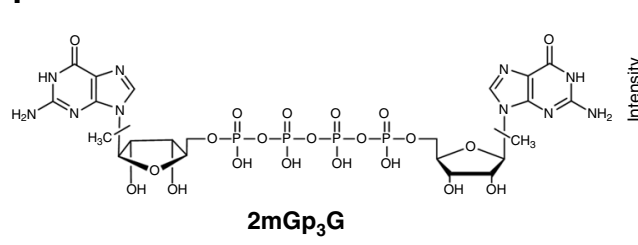
$2 m G p_{3} G$ g

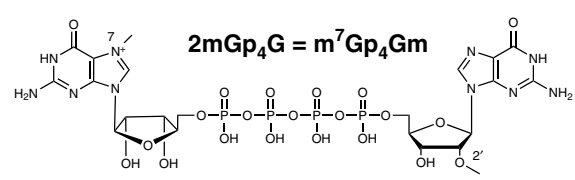

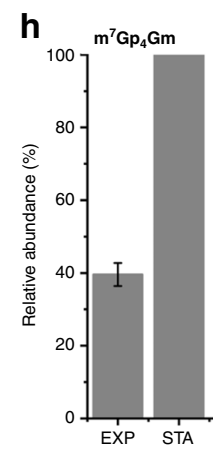
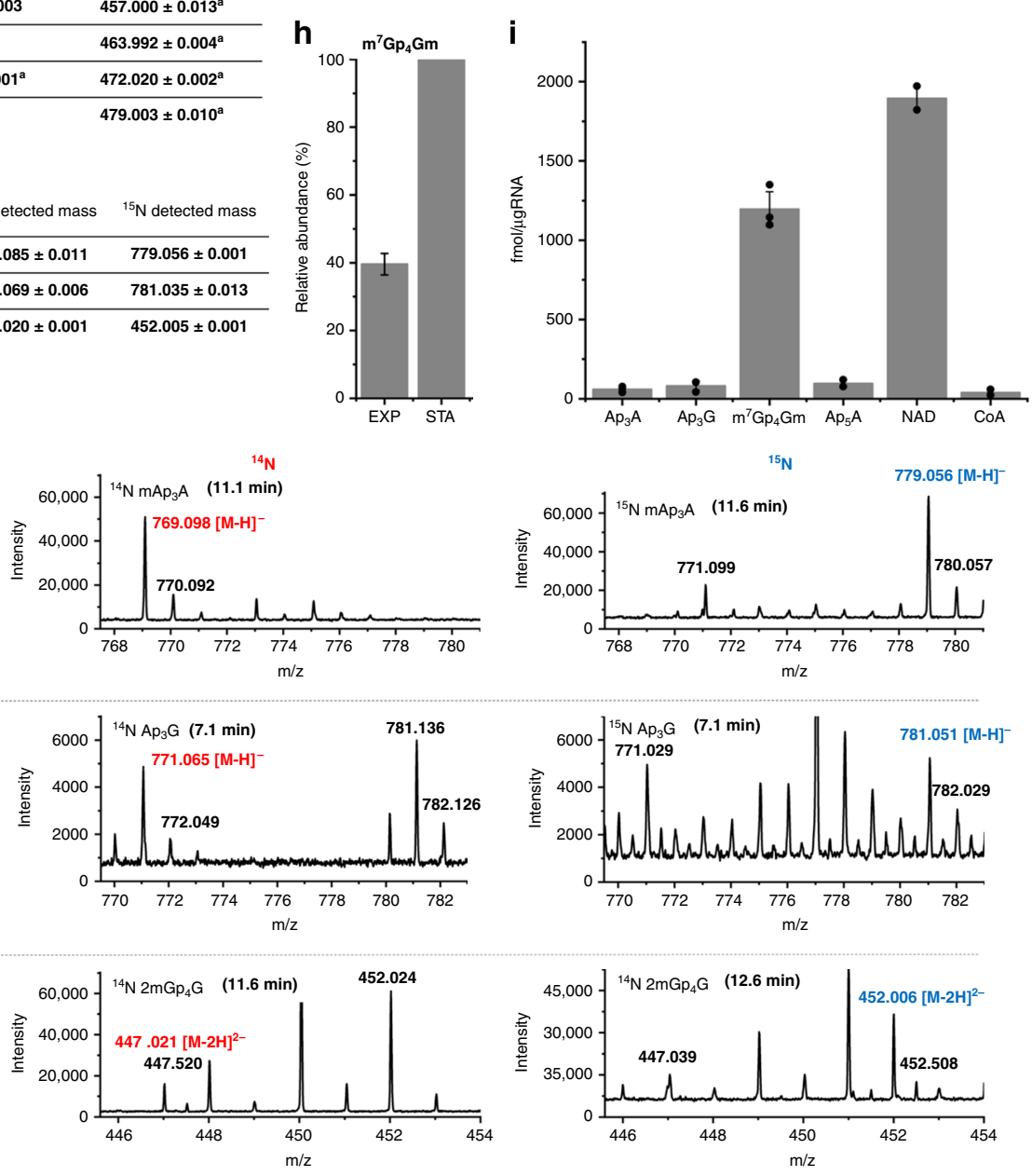

we synthesized all possible mono-methylated $A_{3}{ }_{3} A: m^{6} A p_{3} A$, $\mathrm{m}^{1} \mathrm{Ap}_{3} \mathrm{~A}$, and $\mathrm{Amp}_{3} \mathrm{~A}$ (Supplementary Fig. 9, Supplementary Fig. 20). Based on its retention time, we successfully identified $\mathrm{m}^{7} \mathrm{Gp}_{4} \mathrm{Gm}$ as one of the caps (Fig. $2 \mathrm{~g}$, Supplementary Fig. 10). The fragmentation and retention time of the fragmented methylated $\mathrm{Ap}_{3} \mathrm{~A}$ standards $\left(\mathrm{m}^{6} \mathrm{Ap}_{3} \mathrm{~A}, \mathrm{~m}^{1} \mathrm{Ap}_{3} \mathrm{~A}\right.$, and $\left.\mathrm{Amp}_{3} \mathrm{~A}\right)$ helped us to identify $\mathrm{m}^{6} \mathrm{Ap}_{3} \mathrm{~A}$ as another cap in E. coli RNA (Fig. 2g, Supplementary Fig. 11).

$\mathrm{Np}_{n} \mathrm{~N}$ caps quantification. We compared the amounts of $\mathrm{m}^{7} \mathrm{Gp}_{4} \mathrm{Gm}-\mathrm{RNA}$ at various growth stages. The amount of this cap was more than two-fold higher in STA compared to EXP (Fig. 2h). 
Fig. 2 LC-MS detection of naturally occurring $\mathbf{N} \mathbf{p}_{\boldsymbol{n}} \mathbf{N}-\mathbf{R N A}$ in E. coli. a Scheme showing the RNA preparation for comparative LC-MS measurements. Short RNA was isolated from E. coli in two growth stages. sRNA was washed from non-covalently bound small molecules by size-exclusion chromatography (SEC) and divided into two parts. One part was treated by Nuclease P1, the other was treated under identical conditions without the addition of Nuclease P1 as negative control. Both samples were subjected to SEC again and the fraction of small molecules was analyzed by LC-MS. $\mathbf{b}$ Table of detected $m / z$ values in LC-MS analysis of digested SRNA from E. coli harvested in EXP and STA (all experiments were performed in biological triplicates). $\mathbf{c}$ Table of detected $\mathrm{m} / z$ values in LC-MS analysis of digested sRNA from $E$. coli after growth in minimal media with the sole source of nitrogen from ${ }^{14} \mathrm{NH}_{4} \mathrm{Cl}\left({ }^{14} \mathrm{~N}\right)$ or ${ }^{15} \mathrm{NH}_{4} \mathrm{Cl}$ $\left({ }^{15} \mathrm{~N}\right)$ (all experiments were performed in biological triplicates). d-f Structures of different RNA caps and MS spectra of the detected $m / z$ in RNA from $E$. coli growth in minimal media containing ${ }^{14} \mathrm{~N}$ or ${ }^{15} \mathrm{~N}$ of methyl-Ap $\mathrm{p}_{3} \mathrm{~A}\left(\mathbf{d} \mathrm{m} / \mathrm{z} 769.098\right.$ in ${ }^{14} \mathrm{~N}, \mathrm{~m} / z 779.056$ in $\left.{ }^{15} \mathrm{~N}\right), \mathrm{Ap}_{3} \mathrm{G}\left(\mathbf{e} \mathrm{m} / z 771.065\right.$ in ${ }^{14} \mathrm{~N}, \mathrm{~m} / z 781.051$ in $\left.{ }^{15} \mathrm{~N}\right)$, and dimethyl-Gp $\mathrm{p}_{4} \mathrm{G}\left(\mathbf{f} \mathrm{m} / z 447.021\right.$ in ${ }^{14} \mathrm{~N}, \mathrm{~m} / z$ 452.006 in $\left.{ }^{15} \mathrm{~N}\right)$. g Chemical structure of $\mathrm{m}^{7} \mathrm{Gp}_{4} \mathrm{Gm}$ and $\mathrm{m}^{6} \mathrm{Ap}{ }_{3} \mathrm{~A}$ caps detected in $E$. coli RNA. h Relative quantification of $\mathrm{m}^{7} \mathrm{Gp}_{4} \mathrm{Gm}$ cap in RNA from EXP and STA growth of $E$. coli (experiments were performed in biological triplicates). $\mathbf{i}$ Absolute quantification of $A p_{3} A, A p_{3} G, m^{7} G p_{4} G m, A p_{5} A, N A D$, and CoA RNA caps in RNA from STA growth of $E$. coli. All experiments were performed in triplicates and calculated as average values. Error bars indicate standard deviations. Source data are provided in the Source Data file.

In general, a higher number of methylated $\mathrm{Np}_{n} \mathrm{Ns}$ was detected in this phase. This may indicate that the cells in STA lack nutrients and methylate the $\mathrm{Np}_{n} \mathrm{~N}$-caps to preserve RNA. We also performed an absolute quantification for $\mathrm{Ap}_{3} \mathrm{~A}, \mathrm{Ap}_{3} \mathrm{G}, \mathrm{Ap} \mathrm{p}_{5} \mathrm{~A}$, and $\mathrm{m}^{7} \mathrm{Gp}_{4} \mathrm{Gm}$, and we compared it with the concentration of known RNA caps, i.e., NAD and CoA in STA (Fig. 2i, Supplementary Fig. 12). While the amount of $A p_{3} A, A p_{3} G$, and $A p_{5} A$ was comparable with CoA $(\backsim 75$ fmol per $\mu \mathrm{g}$ of sRNA), the concentration of $\mathrm{m}^{7} \mathrm{Gp}_{4} \mathrm{Gm}$ was significantly higher ( $1200 \mathrm{fmol}$ per $\mu \mathrm{g}$ of sRNA) and comparable to NAD (1900 fmol per $\mu \mathrm{g}$ of sRNA).

$\mathrm{Np}_{\boldsymbol{n}} \mathrm{N}$-RNA decapping. Since $\mathrm{Np}_{n} \mathrm{~N}$-capped RNAs are produced in $E$. coli, degradation mechanisms of the capped RNA in E. coli must also exist. $A p_{n} A$ have been reported to be in vitro substrates for the E. coli NudiX enzyme NudH (RppH (refs. ${ }^{12,29}$ )) and ApaH (ref. ${ }^{30}$ ). RppH is an E. coli decapping enzyme of $5^{\prime}$-ppp RNA $7,14,31$ and $5^{\prime}$-diphosphate $\mathrm{RNA}^{8}$. To assess whether $\mathrm{Ap}_{n} \mathrm{~A}$-capped RNA can be an $\mathrm{RppH}$ or ApaH substrate in vivo, we prepared $\mathrm{Np}_{n} \mathrm{~N}$ - and NAD-capped RNA by in vitro transcription, and tested the products as substrates for both enzymes. First, we added RppH or ApaH, to cleave the $5^{\prime}$-capped RNA (Fig. 3a, c) and we analyzed the products by polyacrylamide gel electrophoresis (PAGE; Fig. 3b, d). We then added the terminator to selectively digest 5 '-p RNA (Supplementary Fig. 13a, b). Electrophoretic analysis showed that $\mathrm{RppH}$ cleaves $5^{\prime}$ ppp RNA and all the $\mathrm{Np}_{n} \mathrm{~N}$-capped RNA into $5^{\prime}$-p RNA. Ap ${ }_{4-6} \mathrm{~A}$ and $\mathrm{Ap}_{4-5} \mathrm{G}$-capped RNAs are excellent substrates for $\mathrm{RppH}$ in vitro. However, $\mathrm{Ap}_{3} \mathrm{~A}-$-, NAD-RNA, and 5'-ppp RNA are cleaved less efficiently (Fig. 3b). ApaH also efficiently decapped all the $\mathrm{Np}_{n} \mathrm{~N}$ RNA but left the $5^{\prime}$-ppp RNA intact (Fig. 3d). Electrophoretic analysis of ApaH decapped RNA treated with the terminator showed that $\mathrm{Ap}_{3-4} \mathrm{~N}-\mathrm{RNA}$ are cleaved into the form of $5^{\prime}-\mathrm{p}$ RNA. In contrast, the decapping reaction of $A p_{5-6} \mathrm{~N}-\mathrm{RNA}$ lead to $5^{\prime}$-pp RNA or $5^{\prime}$-ppp RNA that cannot be degraded by terminator (Supplementary Fig. 13 b). Because NudC was recently reported as a decapping enzyme of NAD-RNA ${ }^{1,5}$, we also tested $\mathrm{Np}_{n} \mathrm{~N}$-capped RNA as substrates of this enzyme. The only decapping activity was observed for NAD-RNA and $\mathrm{Np}_{n} \mathrm{~N}-\mathrm{RNA}$ stayed intact after the NudC treatment (Supplementary Fig. 14).

To understand the substrate specificity of $\mathrm{RppH}$ and $\mathrm{ApaH}$, we performed a kinetic study of $\mathrm{Np}_{n} \mathrm{~N}$-capped RNA. The decapping reaction of $A_{4-5} \mathrm{~N}$ RNA by $\mathrm{RppH}$ was efficient and within 5 min $\sim 80 \%$ of capped RNA was cleaved. While the corresponding $5^{\prime}$-ppp RNA was only decapped by $50 \%$ after $40 \mathrm{~min}$ (Supplementary Fig. 15). ApaH cleaved all the $\mathrm{Np}_{n} \mathrm{~N}-\mathrm{RNA}$ with similar efficiency and only $5^{\prime}$-ppp RNA stayed intact (Supplementary Fig. 16). When we compared the decapping efficiency of both enzymes, we observed the most pronounced differences for 5'-ppp RNA and for $\mathrm{Np}_{n} \mathrm{~N}$-RNA containing longer phosphate bridge (Fig. 3e).

$\mathrm{Np}_{n} \mathbf{N}$ cap methylation role. To reveal the effect of $\mathrm{Np}_{n} \mathrm{~N}$-cap methylation on the RNA, we attempted to prepare model $\mathrm{m}^{7} \mathrm{Gp} \mathrm{p}_{4} \mathrm{Gm}-\mathrm{RNA}$ as a substrate for RppH. Unfortunately, all the methylated forms of $\mathrm{Gp}_{4} \mathrm{G}$ (i.e., $\mathrm{m}^{7} \mathrm{Gp}_{4} \mathrm{Gm}, \mathrm{m}^{1} \mathrm{Gp}_{4} \mathrm{Gm}$, and $\mathrm{m}^{2} \mathrm{Gp}_{4} \mathrm{Gm}$ ) are poor substrates for the T7 RNAP (Supplementary Fig. 17), which prevents subsequent in vitro studies.

To overcome this problem, we used E. coli isolated RNA naturally containing $\mathrm{m}^{7} \mathrm{Gp}_{4} \mathrm{Gm}-\mathrm{RNA}$. We added $\mathrm{RppH}$ into the mixture of isolated sRNA with a spiked model Gp $\mathrm{g}_{4} \mathrm{G}-\mathrm{RNA}$ to compare the activity of $\mathrm{RppH}$ on methylated and non-methylated substrates. We found that the majority of the model $\mathrm{Gp}_{4} \mathrm{G}-\mathrm{RNA}$ was cleaved within $1 \mathrm{~h}$, while the amount of naturally present $\mathrm{m}^{7} \mathrm{Gp}_{4} \mathrm{Gm}$-cap remained unchanged (Fig. 4a). A similar effect was also observed for the methylated forms of $\mathrm{Ap}_{5} \mathrm{G}$ (Supplementary Fig. 18). The spiked Ap $\mathrm{p}_{5} \mathrm{G}-\mathrm{RNA}$ was cleaved within $1 \mathrm{~h}$, but the amount of the $\mathrm{mAp} \mathrm{p}_{5} \mathrm{G}$-cap decreased by $25 \%$ and the $2 \mathrm{mAp}_{5} \mathrm{G}$-cap stayed intact. This confirms that the methylation protects the $\mathrm{Np}_{n} \mathrm{~N}$-capped RNA from cleavage by RppH.

We also tested ApaH (the same concentration as $\mathrm{RppH}$ ) on the mixture of isolated sRNA with a spiked model $\mathrm{Gp}_{4} \mathrm{G}-\mathrm{RNA}$. Surprisingly, the naturally occurring $\mathrm{m}^{7} \mathrm{Gp}_{4} \mathrm{G}$ and model $\mathrm{Gp}_{4} \mathrm{G}$ caps were completely cleaved within $1 \mathrm{~h}$ (Fig. $4 \mathrm{a}$ ).

To unravel the possible molecular basis for the inertness of RNA with methylated $\mathrm{Np}_{n} \mathrm{~N}$-caps to $\mathrm{RppH}$ cleavage, we performed molecular dynamics (MD) simulations of the interaction between $\mathrm{RppH}$ and two models of $\mathrm{Np}_{n} \mathrm{~N}$-capped RNA $\left(\mathrm{Gp}_{4} \mathrm{G}-\mathrm{G}\right.$ and $\left.\mathrm{m}^{7} \mathrm{Gp}_{4} \mathrm{Gm}-\mathrm{G}\right)$. In the $\mathrm{MD}$ simulations, we observed that the interactions with the arginines R28 and R86 were lost when the methyl groups were present (Fig. 4b). These arginines are responsible for the purines binding via cation- $\pi$ stacking, which is disrupted by the positive charge introduced to the purine ring by the methylation. These findings demonstrate how the methylations of $\mathrm{Np}_{n} \mathrm{~N}$-caps in RNA can hamper the decapping by $\mathrm{RppH}$.

\section{Discussion}

In summary, we identified $\mathrm{Np}_{n} \mathrm{Ns}$ as $5^{\prime}$-RNA caps, which are incorporated into RNA by highly divergent RNAPs. We found that $\mathrm{Np}_{n} \mathrm{~N}$ RNA was cleaved by the E. coli $\mathrm{RppH}$ and $\mathrm{ApaH}$ decapping enzymes. Caps with long polyphosphate chains were cleaved the most efficiently and are better substrates for $\mathrm{RppH}$ than 5'-ppp RNA, while ApaH did not show any specific selectivity and cleaved all the $\mathrm{Np}_{n} \mathrm{~N}$ caps. The main difference between these enzymes, is the inability of ApaH to cleave 5'-ppp RNA. In the cells, we detected the presence of both methylated and nonmethylated $\mathrm{Np}_{n} \mathrm{Ns}$ in the sRNA. We determined the positions of the methyl groups in $\mathrm{m}^{7} \mathrm{Gp}_{4} \mathrm{Gm}$ and $\mathrm{m}^{6} \mathrm{Ap} \mathrm{p}_{3} \mathrm{~A}$ caps. LC-MS experiments revealed that the methylation protects the caps from $\mathrm{RppH}$ cleavage but not from ApaH cleavage. This suggests that the cell may regulate the presence of $\mathrm{Np}_{n} \mathrm{~N}-\mathrm{RNA}$ by the expression of these two enzymes, as evidenced in Salmonella typhimurium $^{32}$, where the mRNA levels of ApaH are kept at a threefold lower level than those of RppH. In the late stationary phase, the levels of both transcripts decrease significantly in comparison 
a

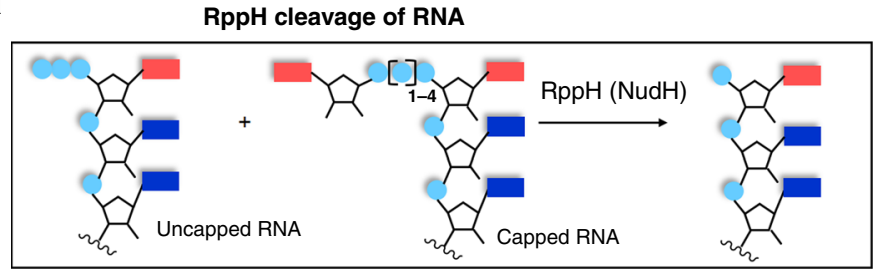

C

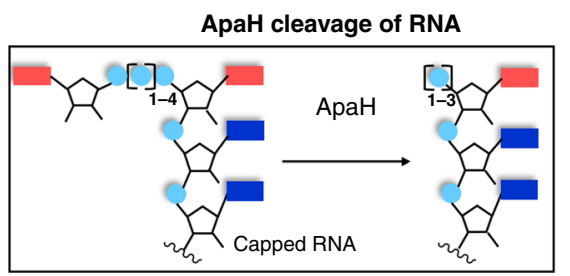

e
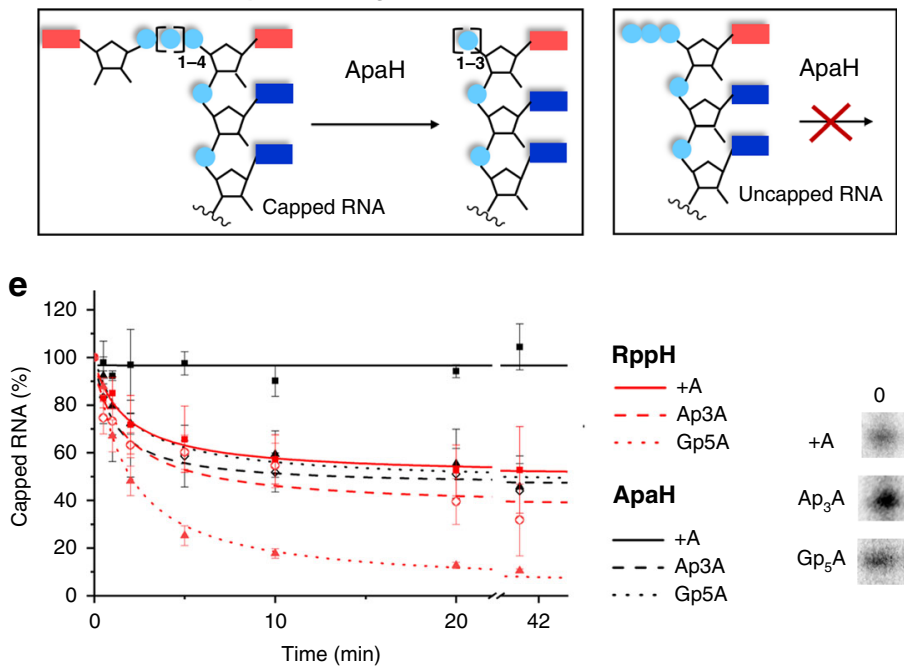

b

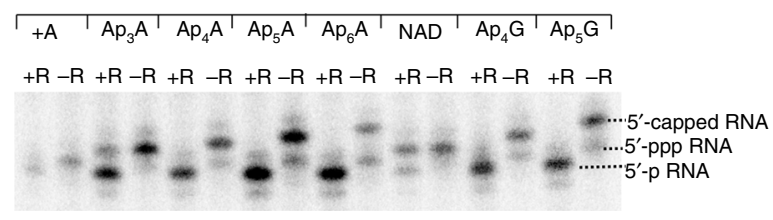

d
ApaH cleavage of RNA

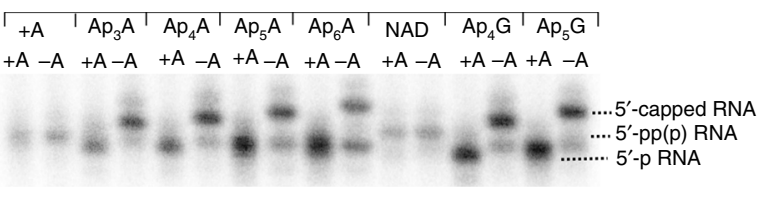

Fig. $3 \mathbf{R p p H}$ and ApaH cleavage of $\mathbf{N p}_{\mathbf{n}} \mathbf{N}$-capped RNA (32P labeled). a Scheme showing the cleavage of capped and uncapped RNA (in vitro transcripted with T7 RNAP) using RppH. b PAGE (12\%) analysis of the ( $\alpha$ - 32 P GTP labeled) in vitro transcribed RNA (35 nt) treated with RppH (+R) or without RppH ( $-R$; all the experiments were performed in triplicates). c Scheme showing the cleavage of capped and uncapped RNA (in vitro transcripted with T7 RNAP) using ApaH. d PAGE (12\%) analysis of in vitro transcribed RNA (35 nt) treated with ApaH ( + A) or without ApaH ( $-\mathrm{A}$; all the experiments were performed in triplicates). e Kinetic studies of RppH (red curves) and ApaH (black curves) cleavage of 5'-ppp RNA (solid line), Ap ${ }_{3} A-R N A$ (dashed line), and Gp ${ }_{5} A-$ RNA (dotted line; $35 \mathrm{nt}$ ) stopped after $30 \mathrm{~s}, 1,2,5,10,20$, and 40 min and analyzed by PAGE (12\%). All experiments were performed in triplicates and calculated as average values. Error bars indicate standard deviations. Source data are provided in the Source Data file.

with the exponential phase (Supplementary Fig. 19). This is in accordance with our finding that the highest amount of methylated $\mathrm{Np}_{n} \mathrm{~N}$ caps is in STA. Hence, we propose that bacteria use methylated caps to stabilize some RNA under stress (Fig. 4c). In exponential phase, the metabolism is at its highest, and the turnover of macromolecules is fast. The methylated caps are therefore not necessary and were detected in low amounts. In contrast, in stationary phase cells lack nutrients and a strategy is needed to conserve these macromolecules. The methylation of the $\mathrm{Np}_{n} \mathrm{~N}$-caps can be a way to preserve important RNA molecules. When the cell returns to physiological conditions, more ApaH is expressed leading to the degradation of methylated $\mathrm{Np}_{n} \mathrm{~N}-\mathrm{RNA}$. In this way, the cell can get back to the fast turnover of macromolecules. In human cells, it has been shown that the N6-methylation of the first encoded nucleotide $\left(\mathrm{m}^{6} \mathrm{Am}, \mathrm{m}^{6} \mathrm{~A}\right)$ hampers the cleavage of mRNA by NudiX decapping enzyme Dcp2 (ref. ${ }^{33}$ ). Our proposed mechanism correlates with this finding and suggests that the strategy, through which cells protect their RNA against decapping by methylation, is general and may also be found in higher organisms. Concurrently, a work reporting the existence of $\mathrm{Ap}_{4} \mathrm{~N}-\mathrm{RNA}$ caps in E. coli was published ${ }^{34}$. However, we did not detect any of the caps reported therein by our LC-MS technique, as the $\mathrm{Ap}_{4} \mathrm{~N}-\mathrm{RNA}$ caps were detected under different stress conditions using a different detection technique.

In conclusion, it is intriguing to consider the possibility that many functions of $\mathrm{Np}_{n} \mathrm{Ns}$ can be explained via their RNA capping potential. Moreover, the $5^{\prime}$-terminal $\mathrm{Np}_{n} \mathrm{Ns}$ may interact with a wide range of cellular partners and influence, e.g., cellular response to starvation. In the near future, besides searching for the methyltransferases responsible for the methylation of the $\mathrm{Np}_{n} \mathrm{~N}$-caps, the key challenge lies in the development of specific techniques to identify the $\mathrm{Np}_{n} \mathrm{~N}$-capped RNA.

\section{Methods}

General. All chemicals were either purchased from Merck or Jena Biosciences and used without further purification. Oligonucleotides were purchased from Generi Biotech. The list of sequences is present in Supplementary Table 1.

Denaturating polyacrylamide gels (PAGE) were visualized by a Typhoon FLA 9500 imaging system.

In vitro transcription with T7 RNAP. In vitro transcription was performed using a standard protocol ${ }^{23}$ in a $25 \mu \mathrm{L}$ mixture containing: $80 \mathrm{ng} / \mu \mathrm{L}$ of template DNA ( $35 \mathrm{~A}$ or $35 \mathrm{G}$ ), $1 \mathrm{mM}$ UTP, $1 \mathrm{mM} \mathrm{CTP}, 0.8 \mathrm{mM}$ GTP, or $0.8 \mathrm{mM}$ ATP, respectively, and $0.2 \mu \mathrm{L} \alpha^{32} \mathrm{P}$ GTP or $\alpha^{32} \mathrm{P}$ ATP (activity: $9.25 \mathrm{MBq}$ in $25 \mu \mathrm{L}$ ), respectively, $1.6 \mathrm{mM}\left(0.2-1.6 \mathrm{mM}\right.$ for incorporation efficiency experiments) $\mathrm{Np}_{n} \mathrm{Ns}, 5 \%$ dimethyl sulfoxide (DMSO), $0.12 \%$ triton X-100, $12 \mathrm{mM}$ dithiothreitol (DTT), $4.8 \mathrm{mM} \mathrm{MgCl}_{2}$ and $1 \times$ reaction buffer for T7 RNAP and 62.5 units of T7 RNAP (New England BioLabs, NEB). The mixture was incubated for $2 \mathrm{~h}$ at $37^{\circ} \mathrm{C}$. The samples $(3 \mu \mathrm{L})$ were mixed with $3 \mu \mathrm{L}$ of $2 \times$ RNA loading dye (NEB) and analyzed by $12 \%$ PAGE $(600 \mathrm{~V}, 3.5 \mathrm{~h})$.

DNAse I treatment. The DNA template was digested by DNAse I to obtain pure RNA. A total of $25 \mu \mathrm{L}$ of the transcription mixture, $3 \mu \mathrm{L}$ of $10 \times$ reaction buffer for DNAse I ( $10 \mathrm{mM}$ Tris- $\mathrm{HCl}, 2.5 \mathrm{mM} \mathrm{MgCl}_{2}, 0.5 \mathrm{mM} \mathrm{CaCl}_{2}, \mathrm{pH} 7.6$ at $25^{\circ} \mathrm{C}$, supplied with the enzyme), and 4 units of DNAse I (NEB) were incubated at $37^{\circ} \mathrm{C}$ for $60 \mathrm{~min}$. The enzyme was heat deactivated at $75^{\circ} \mathrm{C}$ for $10 \mathrm{~min}$ followed by immediate cooling on ice. All samples were purified on RNA mini Quick Spin Columns (Merck) for further use. 
a

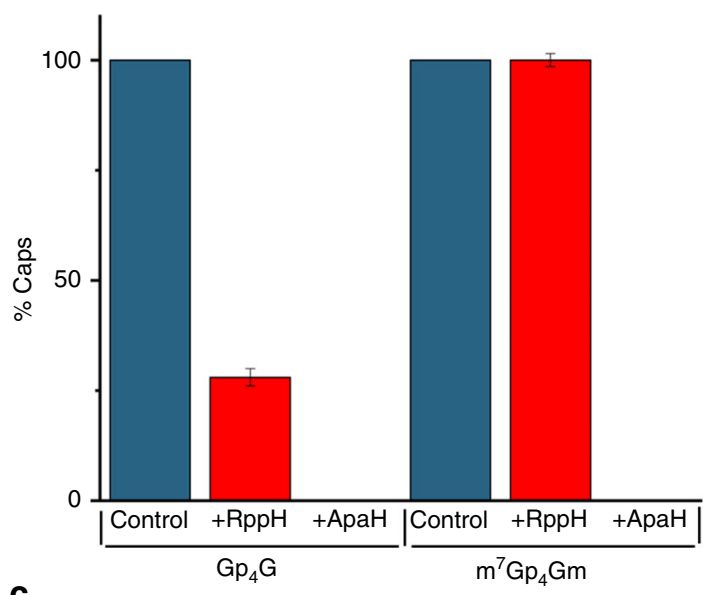

b

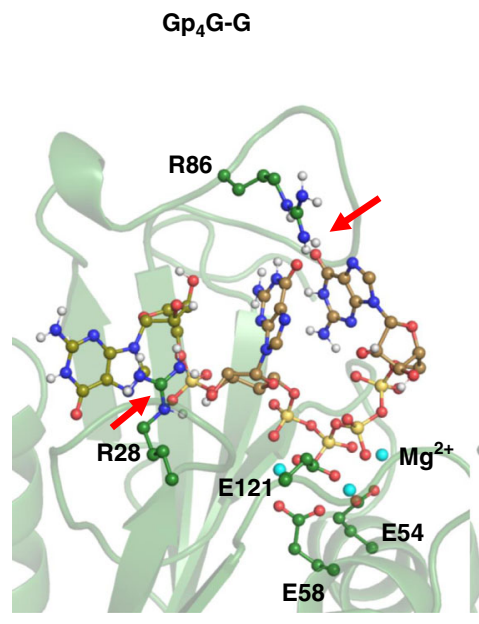

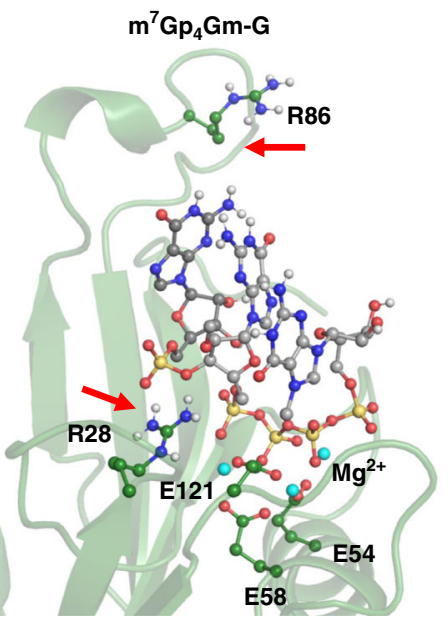

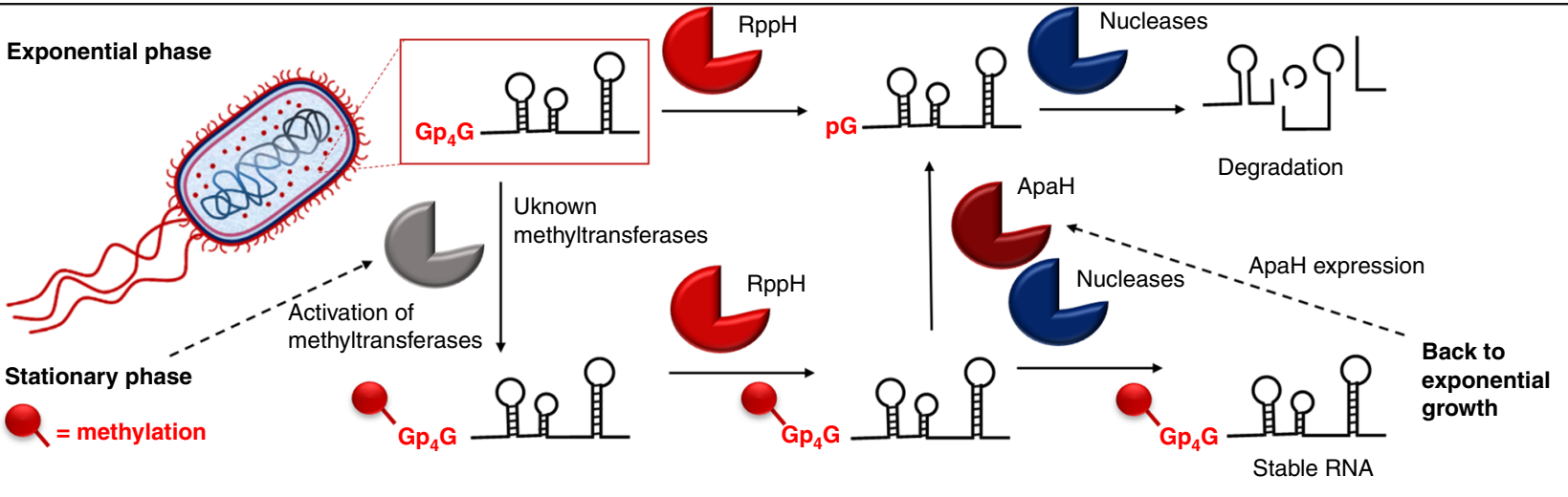

Fig. 4 Role of RppH in the cleavage of $\mathbf{N p}_{\mathbf{n}} \mathbf{N}$-capped RNA in E. coli. a Relative abundance of non-methylated $\mathrm{Gp}_{4} \mathrm{G}$ (left) and $\mathrm{m}^{7} \mathrm{Gp} \mathrm{p}_{4} \mathrm{Gm}$ (right)-RNA as derived from extracted-ion chromatogram (EIC) in the sRNA fraction spiked with $\mathrm{Gp}_{4} \mathrm{G}-\mathrm{RNA}$ before (blue), after $1 \mathrm{~h}$ RppH treatment (red), and after $1 \mathrm{~h}$ $\mathrm{ApaH}$ treatment (all the experiments were performed in biological triplicates). $\mathbf{b}$ Snapshots from molecular dynamics simulation of the interaction of RppH with $\mathrm{Gp}_{4} \mathrm{G}-\mathrm{G}$ and $\mathrm{m}^{7} \mathrm{Gp}_{4} \mathrm{Gm}-\mathrm{G}$ after $200 \mathrm{~ns}$. c Hypothetic cellular processing of RNA in E. coli at different stages of growth. Error bars indicate standard deviations. Source data are provided in the Source Data file.

RNA 5'-polyphosphatase treatment. A total amount of $2.5-3 \mu \mathrm{g}$ of RNA $(10 \mu \mathrm{L})$ were treated with 20 units of $5^{\prime}$-polyphosphatase (Epicenter) in the solution of $1 \times$ buffer in a total volume of $20 \mu \mathrm{L}$ for $1 \mathrm{~h}$ at $37^{\circ} \mathrm{C}$. For the negative control, the enzyme was replaced by the same amount of water. The samples $(3 \mu \mathrm{L})$ were mixed with $3 \mu \mathrm{L}$ of $2 \times$ RNA loading dye and analyzed by $12 \%$ PAGE $(600 \mathrm{~V}, 3.5 \mathrm{~h})$.

Terminator ${ }^{\mathrm{TM}} 5^{\prime}$-phosphate-dependent exonuclease treatment. Because of the incompatibility of the buffers, all samples were purified on RNA mini Quick Spin Columns before the reaction. The RNA (500 ng) was treated with 1 unit of Terminator $^{\text {max }} 5^{\prime}$-phosphate-dependent exonuclease (Epicenter) in the solution of $1 \times$ reaction buffer $\mathrm{A}$ and the mixture was incubated at $30^{\circ} \mathrm{C}$ for $1 \mathrm{~h}$.

E. coli RNAP in vitro transcription. In vitro transcription was performed in a volume of $40 \mu \mathrm{L}$. At first, the mixture contained $10 \mathrm{ng} / \mu \mathrm{L}$ of template plasmid 458 with promoter $r r n B$ P1 or $10 \mathrm{ng} / \mu \mathrm{L}$ of the amplicon FV21 possessing rnaI promoter, $8 \mu \mathrm{L}$ of $5 \times$ buffer, $90 \mathrm{mM} \mathrm{NaCl}, 0.2 \mathrm{mM} \mathrm{ATP}, 0.8 \mathrm{mM} \mathrm{Np}_{n} \mathrm{Ns}$, and 1 unit of E. coli RNAP holoenzyme (NEB). This mixture was preincubated for $10 \mathrm{~min}$ at $37^{\circ} \mathrm{C}$. The transcription was started by addition of an initiation mixture containing $0.2 \mathrm{mM}$ CTP and UTP, $0.15 \mathrm{mM}$ GTP and $0.5 \mu \mathrm{L} \alpha^{32} \mathrm{P}$ GTP (activity: $9.25 \mathrm{MBq}$ in $25 \mu \mathrm{L}$ ) and incubated at $37^{\circ} \mathrm{C}$ for $1 \mathrm{~h}$.

Calculations of capped RNA. The experiments were performed in triplicates and the amount of capped RNA was calculated from PAGE analysis using the software Image ${ }^{35}$. The sum of areas under the peaks corresponding to the $5^{\prime}$-ppp RNA $\left(A r_{p}\right)$ and $5^{\prime}$-capped RNA $\left(A r_{\text {cap }}\right)$ were integrated. The percentage of 5'-capped RNA species were calculated according to: $\left(\mathrm{Ar}_{\text {cap }} / \mathrm{Ar}_{\mathrm{p}}+\mathrm{Ar}_{\mathrm{cap}}\right) \times 100$.

ApaH-cloning and purification. The gene for E. coli ApaH (EG10048) was prepared by PCR (Expand High Fidelity System, Roche) using primers \#3071 and \#3072. Subsequently, the gene was inserted into expression vector pET22b
(Novagen) via unique NdeI and XhoI restriction sites. The additional six histidine residues at the $\mathrm{C}$-terminus served as the His-tag facilitating the protein purification process, and the two residues (amino acids $\mathrm{L}$ and $\mathrm{E}$ ) preceding the His-tag, were inserted because of the restriction enzyme (XhoI) used for cloning. The resulting construct (LK2505) was verified by sequencing. The verified plasmid was transformed into expression strain E. coli DE3 resulting in strain LK2508.

The expression strain LK2508 was grown in rich lysogeny broth (LB) medium containing ampicillin $(100 \mathrm{\mu g} / \mathrm{mL})$ at $37^{\circ} \mathrm{C}$. Expression of ApaH was induced by IPTG $(0.8 \mathrm{mM})$ when $\mathrm{OD}_{600}$ reached 0.6 and the culture was allowed to grow subsequently for $3.5 \mathrm{~h}$ at $25^{\circ} \mathrm{C}$. ApaH was purified similarly to RNAP 36 . Briefly, $1 \mathrm{~L}$ grown culture was harvested by centrifugation $\left(10 \mathrm{~min}, 8000 \times g, 4^{\circ} \mathrm{C}\right)$ and cells were washed with sonication buffer $\left(50 \mathrm{mM} \mathrm{Na}_{2} \mathrm{HPO}_{4}, 300 \mathrm{mM} \mathrm{NaCl}, 5 \%\right.$ glycerol, and $3 \mathrm{mM} 2$-mercaptoethanol). The cells were then resuspended in $25 \mathrm{~mL}$ sonication buffer, sonicated $12 \times 10^{\prime \prime}$ (Hilscher UP200S, Cycle 1, Amplitude 50\%) on ice with $1 \mathrm{~min}$ intervals between sonications, and subsequently centrifuged $\left(10 \mathrm{~min}, 26,000 \times g, 4^{\circ} \mathrm{C}\right)$. The supernatant containing $\mathrm{ApaH}$ was mixed with $1 \mathrm{~mL}$ Ni-NTA agarose (Qiagen, equilibrated with sonication buffer) and incubated for $2 \mathrm{~h}$ on ice (constant mixing). The mixture was then applied on a Poly-Prep chromatography column, washed with $30 \mathrm{~mL}$ sonication buffer and then with $30 \mathrm{~mL}$ sonication buffer containing $30 \mathrm{mM}$ imidazole. ApaH was eluted with sonication buffer containing $400 \mathrm{mM}$ imidazole $(5 \times 0.5 \mathrm{~mL})$ and fractions were analyzed by sodium dodecyl sulfate-PAGE. Purified ApaH was dialyzed into storage buffer $(50 \mathrm{mM}$ Tris- $\mathrm{HCl}, \mathrm{pH} 8,100 \mathrm{mM} \mathrm{NaCl}, 50 \%$ glycerol, and $3 \mathrm{mM} \beta$ mercaptoethanol) and stored at $-20^{\circ} \mathrm{C}$

NudC ${ }^{1}$. The expression strain 1827 was grown in rich LB medium containing kanamycin $(50 \mu \mathrm{g} / \mathrm{mL})$ at $37^{\circ} \mathrm{C}$. Expression of NudC was induced by IPTG $(0.8 \mathrm{mM})$ when $\mathrm{OD}_{600}$ reached 0.5 and the culture was allowed to grow subsequently for $3 \mathrm{~h}$ at $25^{\circ} \mathrm{C}$. The pellet was sonicated $12 \times 10^{\prime \prime}$ (with $50^{\prime \prime}$ intervals between sonications) in Tris buffer (50 mM Tris- $\mathrm{HCl}(\mathrm{pH}$ 8), $1 \mathrm{M} \mathrm{NaCl}, 5 \mathrm{mM}$ $\mathrm{MgSO}_{4}, 5 \mathrm{mM}$ 2-ME, $5 \%$ glycerol, and $5 \mathrm{mM}$ imidazole). The supernatant was mixed with Ni-NTA agarose and washed with $30 \mathrm{~mL}$ Tris buffer and $30 \mathrm{~mL}$ Tris 
buffer with $30 \mathrm{mM}$ imidazole. NudC was eluted with Tris buffer with $400 \mathrm{mM}$ imidazole. Purified NudC was dialyzed into storage buffer $(50 \mathrm{mM}$ Tris- $\mathrm{HCl}(\mathrm{pH}$ 8), $0.5 \mathrm{M} \mathrm{NaCl}, 50 \mathrm{mM} \mathrm{KCl}, 1 \mathrm{mM} \mathrm{MgCl}, 5 \mathrm{mM} \mathrm{DTT}$, and $50 \%$ (v/v) glycerol) and stored at $-80^{\circ} \mathrm{C}$.

Cleavage of capped RNA by RppH, ApaH, or NudC. To test the cleavage of the 5 '-caps, the RNA samples were divided into two parts. The positive control contained $700 \mathrm{ng}$ of the RNA (in vitro transcription, DNAse I treatment, purified on RNA mini Quick Spin Columns), for RppH cleavage: $2 \mu \mathrm{L}$ of $10 \times$ buffer $2(500 \mathrm{mM}$ $\mathrm{NaCl}, 100 \mathrm{mM}$ Tris- $\mathrm{HCl}, 100 \mathrm{mM} \mathrm{MgCl}, 10 \mathrm{mM}$ DTT, pH 7.9 at $25^{\circ} \mathrm{C}$, supplied with the enzyme) and $650 \mathrm{nM} \mathrm{RppH} \mathrm{(NEB).} \mathrm{For} \mathrm{ApaH} \mathrm{or} \mathrm{NudC} \mathrm{cleavage:} 2 \mu \mathrm{L}$ of $10 \times$ buffer NudC $\left(1 \mathrm{M} \mathrm{KCl}, 100 \mathrm{mM}\right.$ Tris- $\mathrm{HCl}, 20 \mathrm{mM} \mathrm{MgCl}_{2}, 20 \mathrm{mM}$ DTT, pH 7.2 at $25^{\circ} \mathrm{C}$ ) and $650 \mathrm{nM} \mathrm{ApaH}$ or $6.5 \mu \mathrm{M} \mathrm{NudC}$. RNA was replaced by water for the negative control. The mixtures were incubated at $37^{\circ} \mathrm{C}$ for $1 \mathrm{~h}$ and purified on RNA mini Quick Spin Columns. A total of $3 \mu \mathrm{L}$ of the purified samples were mixed with $3 \mu \mathrm{L}$ of $2 \times$ RNA loading dye for analysis and $6 \mu \mathrm{L}$ were used for the Terminator treatment.

Kinetic studies. For the kinetic studies, RNA samples ( $35 \mathrm{nt})$ after in vitro transcription with a ${ }^{32} \mathrm{P}$ GTP, DNase I treatment, and purification on RNA mini Quick Spin Columns were used. The $20 \mu \mathrm{L}$ mixture contained $2400 \mathrm{ng}$ of the studied RNA, buffer 2, and $65 \mathrm{nM} \mathrm{RppH} \mathrm{enzyme} \mathrm{or} \mathrm{buffer} \mathrm{NudC} \mathrm{and} 65 \mathrm{nM} \mathrm{ApaH}$. The mixture was incubated at $37^{\circ} \mathrm{C}$, aliquots of $2 \mu \mathrm{L}$ were collected at $0,0.5,1,2,5,10$, 20 , and $40 \mathrm{~min}$ and mixed immediately with $2 \mu \mathrm{L}$ of $2 \times$ RNA loading dye. All samples were analyzed by $12 \%$ PAGE. The experiments were performed in triplicates and the amount of capped RNA was calculated from PAGE analysis using the software ImageJ. The areas under the peaks corresponding to $5^{\prime}$-ppp RNA or $5^{\prime}$-capped RNA were integrated and plotted against time by regarding the area at $0 \mathrm{~min}$ as $100 \%$.

E. coli growth condition. The E. coli strain DH5a containing pUC18 was used for studying RNA modification in two different growth conditions: exponential phase and stationary phase. The growths were performed in LB medium (Merck) in the presence of $0.1 \mathrm{mg} / \mathrm{mL}$ of Ampicillin (Amp, Merck). Parallel cultures of E. coli were inoculated in Erlenmeyer flasks from cultures grown on LB Agar. Cultures (1 L) were grown at $37^{\circ} \mathrm{C}$ until an optical density at $600 \mathrm{~nm}\left(\mathrm{OD}_{600}\right)$ of 0.3 was reached (exponential phase, EXP). Cultures $(1 \mathrm{~L})$ were harvested after $2 \mathrm{~h}$ they reached an $\mathrm{OD}_{600}$ of 1.6 (stationary phase, STA). All cells were harvested by centrifugation at $5000 \times g$ for $10 \mathrm{~min}$. The pellets were washed once with PBS and stored at $-80^{\circ} \mathrm{C}$.

${ }^{14} \mathbf{N} /{ }^{15} \mathbf{N}$ isotope RNA labeling. E. coli strains DH5a containing pUC18 were grown in M9 minimal medium containing $1 \times \mathrm{M} 9$ salts $(5 \times$ concentrate: $34 \mathrm{~g} / \mathrm{L}$ $\mathrm{Na}_{2} \mathrm{HPO}_{4}, 29 \mathrm{~g} / \mathrm{L}$ of $\mathrm{KH}_{2} \mathrm{PO}_{4}, 2.5 \mathrm{~g} / \mathrm{L}$ of $\mathrm{NaCl}$, and $\left.5 \mathrm{~g} / \mathrm{N} \mathrm{N}_{4} \mathrm{Cl}\right), 2 \mathrm{mM} \mathrm{MgSO}_{4}$, $0.1 \mathrm{mM} \mathrm{CaCl}_{2}$, and $0.4 \%$ glucose). The growth was performed in the presence of $0.1 \mathrm{mg} / \mathrm{mL}$ of Amp. Parallel cultures (1 L each) containing ${ }^{14} \mathrm{NH}_{4} \mathrm{Cl}$ or ${ }^{15} \mathrm{NH}_{4} \mathrm{Cl}$ (as sole source of nitrogen) were inoculated in Erlenmeyer flasks from cultures grown overnight in M9 medium $(50 \mathrm{~mL})$. All cells were harvested by centrifugation at $5000 \times g$ for $10 \mathrm{~min}$ after $48 \mathrm{~h}$ of growth $(\mathrm{OD}=0.5)$, washed once with PBS and stored at $-80^{\circ} \mathrm{C}$.

Isolation and purification of sRNA. sRNA from E. coli was isolated using the RNAzol protocol (Merck). The pellets (stemming from $1 \mathrm{~L}$ culture of exponential growth and from $0.5 \mathrm{~L}$ stationary phase growth) were suspended in $4 \mathrm{~mL}$ lysozyme solution $\left(1 \mathrm{mg} / \mathrm{mL}\right.$, Merck) each and incubated for $1 \mathrm{~h}$ at $7{ }^{\circ} \mathrm{C}$. RNAzol $(10 \mathrm{~mL})$ was added to the lysate to isolate the RNA. After shaking vigorously for $15 \mathrm{~s}$, the mixture was incubated for $15 \mathrm{~min}$ on ice and centrifuged at $6000 \times g$ for $45 \mathrm{~min}$. In this step, the DNA, proteins, and most polysaccharides formed a semisolid pellet at the bottom of the tube. The RNA, which remained in the supernatant, was mixed with 0.4 volumes of $75 \%$ ethanol $(\mathrm{v} / \mathrm{v})$. After storing on ice for $10 \mathrm{~min}$, the sample was centrifuged at $6000 \times g$ for $16 \mathrm{~min}$ for pelleting the long RNA. The supernatant containing sRNA was mixed with 0.8 volumes of isopropanol. After storing on ice for $30 \mathrm{~min}$, the sample was centrifuged at $6000 \times g$ for $40 \mathrm{~min}$ for pelleting the sRNA. The pellets containing the long and sRNA were washed twice with $75 \%$ ethanol (v/v) and 70\% isopropanol $(\mathrm{v} / \mathrm{v})$, respectively. Both pellets were dissolved in small amounts of water and stored at $-80^{\circ} \mathrm{C}$. To remove possible contaminants, all sRNA samples were submitted to size-exclusion chromatography for five times using an Amicon Ultra $3 \mathrm{KDa}$ cut-off (Merck). All experiments were performed in at least triplicates.

RppH and ApaH experiments with sRNA. sRNA ( $1 \mathrm{mg})$ from stationary phase was spiked with $10 \mu \mathrm{g}$ of model $\mathrm{Gp}_{4} \mathrm{G}-\mathrm{RNA}$ or $\mathrm{Ap}_{5} \mathrm{G}-\mathrm{RNA}$ and divided into two halves. The first part was diluted to a final volume of $300 \mu \mathrm{L}$ with $30 \mu \mathrm{L}$ of $10 \times$ buffer 2 (for RppH) or with $10 \times$ buffer NudC (for ApaH) and RppH (NEB), or ApaH were added to reach the final concentration of $5 \mu$. The second half was used as a negative control and also diluted to a final volume of $300 \mu \mathrm{L}$ using buffer without the addition of RppH. The mixtures were incubated at $37^{\circ} \mathrm{C}$ for $1 \mathrm{~h}$, and further used for LC-MS analysis.
SRNA digestion for LC-MS. A total amount of $1 \mathrm{mg}$ of sRNA was divided into two aliquots; one aliquot of $0.5 \mathrm{mg}$ was digested by $10 \mathrm{U}$ of Nuclease P1 (Merck) in 50 $\mathrm{mM}$ ammonium acetate buffer $(\mathrm{pH} 4.5)$ at $37^{\circ} \mathrm{C}$ for $1 \mathrm{~h}$. The second aliquot of 0.5 $\mathrm{mg}$ was incubated without enzyme and used as negative control. The digest was purified over Amicon-Millipore filters $10 \mathrm{kDa}$ (Merck). The flow through was dried up on a Speedvac system and dissolved in $10 \mu \mathrm{L}$ of a mixture of acetonitrile (10\%) and ammonium acetate $(10 \mathrm{mM}, \mathrm{pH} 12)$. The final $\mathrm{pH}$ was adjusted to 10 using a solution of $\mathrm{NaOH}$.

In vitro transcription with T7 RNAP for synthesis of pppGpG. In vitro transcription was performed in the $50 \mu \mathrm{L}$ mixture containing $120 \mathrm{ng} / \mu \mathrm{L}$ of template DNA (2ntG), $2.0 \mathrm{mM}$ GTP, 5\% DMSO, 0.12\% triton X-100, $12 \mathrm{mM}$ DTT, $4.8 \mathrm{mM}$ magnesium chloride, and $1 \times$ reaction buffer for T7 RNAP and 125 units of T7 RNAP. The mixture was incubated for $2 \mathrm{~h}$ at $37^{\circ} \mathrm{C}$. The mixture was filtered on an Amicon Ultra 0.5 Centrifugal Filter $3 \mathrm{kDa}$ (Merck), which was then washed with water $(2 \times 150 \mu \mathrm{L})$. The combined flow through was evaporated on a Speedvac system.

Synthesis of $\boldsymbol{N}^{\mathbf{1}}$-methyladenosine $\left(\mathbf{m}^{\mathbf{1}} \mathbf{A}\right)^{\mathbf{3 7}, 38}$. Iodomethane $(1.87 \mathrm{~mL}, 30 \mathrm{mmol})$ was added dropwise to a suspension of adenosine $(2 \mathrm{~g}, 7.5 \mathrm{mmol})$ in $\mathrm{N}, \mathrm{N}$-dimethylacetamide $(20 \mathrm{~mL})$. The reaction mixture was stirred overnight at room temperature (RT). Celite $(200 \mathrm{mg})$ was added and the resulting suspension was stirred at RT for $30 \mathrm{~min}$. Afterward, the suspension was filtered and the solids were washed with dry acetone $(100 \mathrm{~mL})$. Product precipitated at $5{ }^{\circ} \mathrm{C}$. After filtration and washing with cold acetone, the product was isolated as an off-white powder in $81 \%$ yield $(1.7 \mathrm{~g}, 6.0 \mathrm{mmol}) .{ }^{1} \mathrm{H}$ nuclear magnetic resonance (NMR) $\left(401 \mathrm{MHz}, \mathrm{D}_{2} \mathrm{O}\right) \delta$ $8.56(\mathrm{~s}, 1 \mathrm{H}), 8.55(\mathrm{~s}, 1 \mathrm{H}), 6.15(\mathrm{~d}, J=5.2 \mathrm{~Hz}, 1 \mathrm{H}), 4.81(1 \mathrm{H}$, overlapped with HDO), $4.46(\mathrm{dd}, J=5.3,4.3 \mathrm{~Hz}, 1 \mathrm{H}), 4.28(\mathrm{td}, J=4.4,3.0 \mathrm{~Hz}, 1 \mathrm{H}), 4.02-3.80(\mathrm{~m}$, $5 \mathrm{H}) \mathrm{ppm} .{ }^{13} \mathrm{C}$ NMR $\left(101 \mathrm{MHz}, \mathrm{D}_{2} \mathrm{O}\right) \delta 151.73,148.49,147.56,143.87,120.05$, $89.21,86.15,74.83,70.80,61.75,38.51 \mathrm{ppm}$. MS $\left(\mathrm{ESI}^{+}\right) \mathrm{m} / z$ (\%): 282 (100), 304 $(10,+\mathrm{Na})$. High resolution mass spectrometry (HRMS) (ESI) $\mathrm{m} / z:\left[(\mathrm{M})^{+}\right]\left(\mathrm{C}_{11} \mathrm{H}_{16}\right.$ $\mathrm{O}_{4} \mathrm{~N}_{5}$ ) calc.: 282.11940 , found: 282.11968 .

Synthesis of $\mathbf{N}^{6}$-methyladenosine $\left(\mathbf{m}^{\mathbf{6}} \mathbf{A}\right)^{39} . N^{1}$-methyladenosine $(1.0 \mathrm{~g}, 3.5$ mmol) was suspended in an aqueous solution of $\mathrm{NaOH}(0.25 \mathrm{M}, 50 \mathrm{~mL})$ and heated at $110^{\circ} \mathrm{C}$ for $75 \mathrm{~min}$. Then, the solution was neutralized by addition of $10 \%$ water solution of p-toluenesulfonic acid. Then, water was removed under reduced pressure (maximum bath temperature was always $40^{\circ} \mathrm{C}$ ). Methanol was added to the solid residue and resulting suspension was heated at $80^{\circ} \mathrm{C}$ for $5 \mathrm{~min}$. Methanol was removed under reduced pressure. Finally, the solid residue was suspended in EtOAc and the resulting suspension was refluxed at $80^{\circ} \mathrm{C}$ overnight. After filtration, EtOAc from the liquors was removed on rotary evaporator. Solids were dried under vacuum to get the $N^{6}$-methyladenosine in $50 \%$ yield $(500 \mathrm{mg}, 1.8 \mathrm{mmol}) .{ }^{1} \mathrm{H}$ $\operatorname{NMR}\left(400 \mathrm{MHz}, \mathrm{D}_{2} \mathrm{O}\right) \delta 8.24(\mathrm{~s}, 1 \mathrm{H}), 8.19(\mathrm{~s}, 1 \mathrm{H}), 6.03(\mathrm{~d}, J=6.2 \mathrm{~Hz}, 1 \mathrm{H}), 4.78-$ $4.77(\mathrm{~m}, 1 \mathrm{H}), 4.46-4.37(\mathrm{~m}, 1 \mathrm{H}), 4.29(\mathrm{~d}, J=3.1 \mathrm{~Hz}, 1 \mathrm{H}), 3.97-3.80(\mathrm{~m}, 2 \mathrm{H})$ and $3.07(\mathrm{~s}, 3 \mathrm{H}) \mathrm{ppm} .{ }^{13} \mathrm{C}$ NMR $\left(101 \mathrm{MHz}, \mathrm{D}_{2} \mathrm{O}\right) \delta 154.72,152.16,151.50,139.76$, $125.86,88.27,85.77,73.69,70.62,61.50,29.76 \mathrm{ppm}$. MS (ESI $\left.{ }^{+}\right) \mathrm{m} / z(\%): 282(100)$, $304(90,+\mathrm{Na})$. HRMS (ESI) $m / z:\left[(\mathrm{M})^{+}\right]\left(\mathrm{C}_{11} \mathrm{H}_{16} \mathrm{O}_{4} \mathrm{~N}_{5}\right)$ calc.: 282.11968 , found: 282.11938 .

Monophosphorylation of $\mathbf{m}^{\mathbf{1}} \mathbf{A}, \mathbf{m}^{\mathbf{6}} \mathbf{A}$ and $\mathbf{2}^{\prime}-\mathbf{0}$-methyladenosine. The respective methyladenosine derivative (1 eq.) was suspended in trimethyl phosphate $(0.1 \mathrm{M}$, final concentration). Resulting suspension was cooled at $0^{\circ} \mathrm{C}$ and $\mathrm{POCl}_{3}(2.0$ eq.) was added dropwise. Reaction mixture was stirred at $0{ }^{\circ} \mathrm{C}$ until complete consumption of the starting material according high-performance liquid chromatography (HPLC). Then, water was added and the resulting solution was neutralized with $\mathrm{NaOH} 6 \mathrm{M}$ and $\mathrm{HCl} 1 \mathrm{M}$. The respective methyladenosine monophosphates were isolated after preparative HPLC (A-triethylamonium acetate $0.1 \mathrm{M}, \mathrm{pH} 7.0$, $\mathrm{B}-$ acetonitrile). Then, water from each fraction was removed under reduced pressure. Final compounds were obtained after lyophilisation.

$N^{1}$-methyladenosine $5^{\prime}$-monophosphate (yield $\left.63 \%\right) .{ }^{1} \mathrm{H}$ NMR $\left(401 \mathrm{MHz}, \mathrm{D}_{2} \mathrm{O}\right)$ $\delta 8.63(\mathrm{~s}, 1 \mathrm{H}), 8.52(\mathrm{~s}, 1 \mathrm{H}), 6.17(\mathrm{~d}, J=5.4 \mathrm{~Hz}, 1 \mathrm{H}), 4.77(1 \mathrm{H}$, overlapped with HDO), 4.51 (dd, $J=5.1,3.8 \mathrm{~Hz}, 1 \mathrm{H}), 4.39(\mathrm{dq}, J=5.3,3.0 \mathrm{~Hz}, 1 \mathrm{H}), 4.22-4.06$ $(\mathrm{m}, 2 \mathrm{H}), 3.93(\mathrm{~s}, 3 \mathrm{H}) \mathrm{ppm} .{ }^{13} \mathrm{C}$ NMR $\left(101 \mathrm{MHz}, \mathrm{D}_{2} \mathrm{O}\right) \delta 151.03,147.95,147.16$, $142.82,118.98,88.01,84.52,74.76,70.44,64.35,37.76,8.28$ ppm. MS $\left(\mathrm{ESI}^{+}\right) \mathrm{m} / \mathrm{z}$ (\%): $362(100), 384(25,+\mathrm{Na})$. HRMS (ESI) $\mathrm{m} / \mathrm{z}:\left[(\mathrm{M})^{+}\right]\left(\mathrm{C}_{11} \mathrm{H}_{17} \mathrm{O}_{7} \mathrm{~N}_{5} \mathrm{P}\right)$ calc.: 362.08601, found: 362.08607

$N^{6}$-methyladenosine $5^{\prime}$-monophosphate (yield $\left.31 \%\right)^{39}$. ${ }^{1} \mathrm{H}$ NMR $(401 \mathrm{MHz}$, $\left.\mathrm{D}_{2} \mathrm{O}\right) \delta 8.25(\mathrm{~s}, 1 \mathrm{H}), 7.99(\mathrm{~s}, 1 \mathrm{H}), 5.94(\mathrm{~d}, J=5.7 \mathrm{~Hz}, 1 \mathrm{H}), 4.60(\mathrm{t}, J=5.4 \mathrm{~Hz}, 1 \mathrm{H})$ $4.38(\mathrm{dd}, J=5.2,3.7 \mathrm{~Hz}, 1 \mathrm{H}), 4.27(\mathrm{dd}, J=3.6,2.2 \mathrm{~Hz}, 1 \mathrm{H}), 4.03(\mathrm{td}, J=5.0$, $3.0 \mathrm{~Hz}, 2 \mathrm{H}), 2.94-2.85(\mathrm{~m}, 3 \mathrm{H}) \mathrm{ppm} .{ }^{13} \mathrm{C}$ NMR $\left(101 \mathrm{MHz}, \mathrm{D}_{2} \mathrm{O}\right) \delta 154.30$, 152.04, 150.72, 139.16, 118.50, 87.00, 84.05, 83.96, 70.46, 64.48, 29.66 ppm. MS $\left(\mathrm{ESI}^{-}\right) \mathrm{m} / z(\%): 360(100), 382(10,+\mathrm{Na})$. HRMS (ESI) $\mathrm{m} / z:\left[(\mathrm{M})^{-}\right]\left(\mathrm{C}_{11} \mathrm{H}_{15}\right.$ $\mathrm{O}_{7} \mathrm{~N}_{5} \mathrm{P}$ ) calc.: 360.07146 , found: 360.07108

$2^{\prime}$-O-methyladenosine $5^{\prime}$-monophosphate (yield $\left.47 \%\right)^{40}$. ${ }^{1} \mathrm{H}$ NMR $(401 \mathrm{MHz}$, $\left.\mathrm{D}_{2} \mathrm{O}\right) \delta 8.39(\mathrm{~s}, 1 \mathrm{H}), 8.11(\mathrm{~s}, 1 \mathrm{H}), 6.07(\mathrm{~d}, J=5.9 \mathrm{~Hz}, 1 \mathrm{H}), 4.56(\mathrm{dd}, J=5.1$, $3.4 \mathrm{~Hz}, 1 \mathrm{H}), 4.37(\mathrm{dd}, J=6.0,5.0 \mathrm{~Hz}, 1 \mathrm{H}), 4.28(\mathrm{dd}, J=3.4,2.3 \mathrm{~Hz}, 1 \mathrm{H}), 4.03(\mathrm{td}$, $J=3.0,1.3 \mathrm{~Hz}, 2 \mathrm{H}), 3.36(\mathrm{~s}, 3 \mathrm{H}) \mathrm{ppm} .{ }^{13} \mathrm{C} \mathrm{NMR}\left(101 \mathrm{MHz}, \mathrm{D}_{2} \mathrm{O}\right) \delta 155.09$, $152.22,148.87,140.07,118.51,85.47,84.72,83.26,69.13,64.46,58.22$ ppm. MS 
$\left(\mathrm{ESI}^{-}\right) \mathrm{m} / z(\%): 360(100)$. HRMS (ESI) $m / z:\left[(\mathrm{M})^{-}\right]\left(\mathrm{C}_{11} \mathrm{H}_{15} \mathrm{O}_{7} \mathrm{~N}_{5} \mathrm{P}\right)$ calc.: 360.07146, found: 360.07077 .

Synthesis of adenosine $\mathbf{5}^{\prime}$-diphosphoimidazolide. Adenosine $5^{\prime}$-diphosphate $(0.5 \mathrm{~g}, 1.17 \mathrm{mmol})$, imidazole $(0.64 \mathrm{~g}, 9.4 \mathrm{mmol})$, and 2,2'-dithiopyridine $(0.77 \mathrm{~g}$ $3.5 \mathrm{mmol}$ ) were suspended in dimethylformamide (DMF; $10 \mathrm{~mL}$ ). Then, trimethylamine $(323 \mu \mathrm{L}, 2.3 \mathrm{mmol})$ and triphenylphosphine $(0.92 \mathrm{~g}, 3.5 \mathrm{mmol})$ were added. Resulting suspension was stirred at RT for $24 \mathrm{~h}$. The resulting clear solution was poured into a flask containing anhydrous sodium perchlorate (1 eq.) dissolved in dry and cold acetone $\left(8 \mathrm{~mL}\right.$ per $1.0 \mathrm{~mL}$ of DMF). After cooling at $4{ }^{\circ} \mathrm{C}$ for 30 min, liquids were separated from solids by centrifugation. Resulting solid pellet was washed four times with dry and cold acetone, and was centrifuged each time. Finally, solids were washed with diethyl ether and were centrifuged. Product was isolated as an off-white solid in $45 \%$ yield $(0.25 \mathrm{~g}, 0.52 \mathrm{mmol})$. Solids were dried overnight under vacuum and used in the next step without further purification. MS $\left(\mathrm{ESI}^{+}\right) \mathrm{m} / z(\%): 500(25,+\mathrm{Na}), 522(100,+2 \mathrm{Na}), 544(40,+3 \mathrm{Na})$. HRMS (ESI) $m / z:\left[\mathrm{M}+\mathrm{Na}^{+}\right]\left(\mathrm{C}_{13} \mathrm{H}_{17} \mathrm{O}_{9} \mathrm{~N}_{7} \mathrm{NaP}_{2}\right)$ calc.: 500.04552 , found: 500.04558 .

General synthesis of $\mathbf{m A p} \mathbf{A}$ standards. Respective methyladenosine $5^{\prime}$-monophosphate (1.2 eq.), adenosine $5^{\prime}$-diphosphoimidazolide (1.0 eq.), and dry $\mathrm{MgCl}_{2}$ (3 eq.) were suspended in dry DMF. Resulting suspension was stirred at RT for $6 \mathrm{~h}$. The reaction was stopped by addition of $\mathrm{H}_{2} \mathrm{O}$. Products were isolated after preparative HPLC (A-triethylammonium acetate $0.1 \mathrm{M}, \mathrm{pH} 7, \mathrm{~B}$-acetonitrile). Codistillations with water followed by several freeze-drying from water gave off-white solid products.

P1-[5'-(N'-methyladenosyl)] P3-(5'-adenosyl) triphosphate (yield $\mathbf{4 0 \% )}{ }^{1} \mathrm{H}$ NMR $\left(500 \mathrm{MHz}, \mathrm{D}_{2} \mathrm{O}\right.$, internal ref. $\left.t \mathrm{BuOH}, 1.24 \mathrm{ppm}\right) \delta 8.50(\mathrm{~s}, 1 \mathrm{H}), 8.45(\mathrm{~d}, J=$ $2.5 \mathrm{~Hz}, 1 \mathrm{H}), 8.31(\mathrm{~s}, 1 \mathrm{H}), 8.15(\mathrm{~s}, 1 \mathrm{H}), 6.08(\mathrm{~d}, J=5.1 \mathrm{~Hz}, 1 \mathrm{H}), 6.03(\mathrm{~d}, J=$ $5.4 \mathrm{~Hz}, 1 \mathrm{H}), 4.74(\mathrm{t}, J=5.0 \mathrm{~Hz}, 1 \mathrm{H}), 4.70(\mathrm{t}, J=5.2 \mathrm{~Hz}, 1 \mathrm{H}), 4.53(\mathrm{dt}, J=9.3$, $4.5 \mathrm{~Hz}, 2 \mathrm{H}), 4.39-4.21(\mathrm{~m}, 6 \mathrm{H}), 3.86(\mathrm{~s}, 3 \mathrm{H}) \mathrm{ppm} .{ }^{13} \mathrm{C}$ NMR $\left(125.7 \mathrm{MHz}, \mathrm{D}_{2} \mathrm{O}\right.$, internal ref. $t \mathrm{BuOH}, 32.43 \mathrm{ppm}) \delta 157.91,155.55,153.17,151.45,150.71,149.42$, $145.38,142.31,121.06,120.73,90.68,89.61,86.79-86.72\left(\mathrm{~d}, J=9.1 \mathrm{~Hz}, \mathrm{C}_{4^{\prime}}\right)$, $86.42-86.34\left(\mathrm{~d}, J=9.1 \mathrm{~Hz}, \mathrm{C}_{4}\right), 77.83,77.54,72.94,72.91,67.85-67.81(\mathrm{~d}, J=$ $\left.5.3 \mathrm{~Hz}, \mathrm{C}_{5}\right), 67.69-67.65\left(\mathrm{~d}, J=5.3 \mathrm{~Hz}, \mathrm{C}_{5}\right), 40.54 \mathrm{ppm} .{ }^{31} \mathrm{P}$ NMR $(202.4 \mathrm{MHz}$, $\mathrm{D}_{2} \mathrm{O}$, external ref. $\left.\mathrm{H}_{3} \mathrm{PO}_{4}, 0.0 \mathrm{ppm}\right) \delta-10.41(\mathrm{dd}, J=19.4,11.4 \mathrm{~Hz}),-21.89(\mathrm{t}, J=$ $19.4 \mathrm{~Hz}) \mathrm{ppm}$. MS $\left(\mathrm{ESI}^{+}\right) \mathrm{m} / z(\%): 771(100)$. HRMS (ESI) $\mathrm{m} / z$ : $\left[\mathrm{M}^{+}\right]\left(\mathrm{C}_{21} \mathrm{H}_{30}\right.$ $\mathrm{O}_{16} \mathrm{~N}_{10} \mathrm{P}_{3}$ ) calc.: 771.10486 , found: 771.10593 .

$\mathbf{P}^{1}$-[5'-( $\mathbf{N}^{6}$-methyladenosyl)] $\mathbf{P}^{\mathbf{3}}$-(5'-adenosyl) triphosphate (yield $\left.\mathbf{3 0} \%\right) .{ }^{1} \mathrm{H}$ $\operatorname{NMR}\left(500 \mathrm{MHz}, \mathrm{D}_{2} \mathrm{O}\right.$, internal ref. $\left.t \mathrm{BuOH}, 1.24 \mathrm{ppm}\right) \delta 8.26(\mathrm{~s}, 1 \mathrm{H}), 8.21(\mathrm{~s}, 1 \mathrm{H})$, $8.09(\mathrm{~m}, J=2.3 \mathrm{~Hz}, 2 \mathrm{H}), 6.01(\mathrm{~d}, J=4.7 \mathrm{~Hz}, 1 \mathrm{H}), 5.99(\mathrm{~d}, J=4.5 \mathrm{~Hz}, 1 \mathrm{H}), 4.63(\mathrm{t}$, $J=4.7 \mathrm{~Hz}, 1 \mathrm{H}), 4.59(\mathrm{t}, J=4.6 \mathrm{~Hz}, 1 \mathrm{H}), 4.49(\mathrm{~d}, J=13.1 \mathrm{~Hz}, 1 \mathrm{H}), 4.37-4.30(\mathrm{~m}$, $5 \mathrm{H}), 4.27(\mathrm{~m}, 2 \mathrm{H}), 2.97(\mathrm{bs}, 3 \mathrm{H}) \mathrm{ppm} .{ }^{13} \mathrm{C}$ NMR $\left(125.7 \mathrm{MHz}, \mathrm{D}_{2} \mathrm{O}\right.$, internal ref. $t \mathrm{BuOH}, 32.43 \mathrm{ppm}) \delta 157.66,157.06,155.39,155.07,150.90,141.74,141.21,120.63$, 90.13, 90.02, $85.91-85.83\left(\mathrm{~d}, J=9.1 \mathrm{~Hz}, \mathrm{C}_{4^{\prime}}\right), 85.79-85.71\left(\mathrm{~d}, J=9.1 \mathrm{~Hz}, \mathrm{C}_{4^{2}}\right)$, $77.85,77.81,72.50,72.36,67.49-67.44\left(\mathrm{~d}, J=5.2 \mathrm{~Hz}, \mathrm{C}_{5^{\prime}}\right), 67.39-67.35(\mathrm{~d}, J=$ $\left.5.3 \mathrm{~Hz}, \mathrm{C}_{5^{\prime}}\right), 25.86$ ppm. ${ }^{31} \mathrm{P}$ NMR $\left(202.4 \mathrm{MHz}, \mathrm{D}_{2} \mathrm{O}\right.$, external ref. $\left.\mathrm{H}_{3} \mathrm{PO}_{4}, 0.0 \mathrm{ppm}\right)$ $\delta-10.42(\mathrm{dd}, J=19.4,5.3 \mathrm{~Hz}),-21.89(\mathrm{t}, J=19.4 \mathrm{~Hz}) \mathrm{ppm}$. MS $\left(\mathrm{ESI}^{-}\right) \mathrm{m} / z(\%):$ 769 (100), $791(80,+\mathrm{Na}), 813(20,+2 \mathrm{Na})$. HRMS (ESI) $\mathrm{m} / z:\left[\mathrm{M}^{-}\right]\left(\mathrm{C}_{21} \mathrm{H}_{28}\right.$ $\mathrm{O}_{16} \mathrm{~N}_{10} \mathrm{P}_{3}$ ) calc.: 769.09031 , found: 769.08953 .

\section{P'-[5'-(2'-0-methyladenosyl)] $\mathbf{P}^{\mathbf{3}}$-(5'-adenosyl) triphosphate (yield 50\%)}

${ }^{1} \mathrm{H}$ NMR $\left(500 \mathrm{MHz}, \mathrm{D}_{2} \mathrm{O}\right.$, internal ref. $\left.t \mathrm{BuOH}, 1.24 \mathrm{ppm}\right) \delta 8.30(\mathrm{~s}, 1 \mathrm{H}), 8.28(\mathrm{~s}, 1$ H), $8.09(\mathrm{~s}, 1 \mathrm{H}), 8.09(\mathrm{~s}, 1 \mathrm{H}), 6.03(\mathrm{~d}, J=4.6 \mathrm{~Hz}, 1 \mathrm{H}), 5.97(\mathrm{~d}, J=5.2 \mathrm{~Hz}, 1 \mathrm{H})$, $4.59(\mathrm{t}, J=5.1 \mathrm{~Hz}, 1 \mathrm{H}), 4.57(\mathrm{t}, J=4.7 \mathrm{~Hz}, 1 \mathrm{H}), 4.48(\mathrm{t}, J=4.6 \mathrm{~Hz}, 1 \mathrm{H}), 4.35-$ $4.24(\mathrm{~m}, 6 \mathrm{H}), 4.21(\mathrm{t}, J=4.8 \mathrm{~Hz}, 1 \mathrm{H}), 3.50(\mathrm{~s}, 3 \mathrm{H}) \mathrm{ppm} .{ }^{13} \mathrm{C} \mathrm{NMR}(125.7 \mathrm{MHz}$, $\mathrm{D}_{2} \mathrm{O}$, internal ref. $\left.t \mathrm{BuOH}, 32.43 \mathrm{ppm}\right) \delta 157.89,157.86,155.40,155.34,151.24$, $150.98,142.18,142.10,120.88,89.85,88.27,86.44,86.26-86.21(\mathrm{~d}, J=9.1 \mathrm{~Hz}$, $\left.\mathrm{C}_{4^{\prime}}\right), 86.20-86.16\left(\mathrm{~d}, J=9.1 \mathrm{~Hz}, \mathrm{C}_{4^{\prime}}\right), 77.60,72.80,71.08,67.77-67.73(\mathrm{~d}, J=$ $\left.5.3 \mathrm{~Hz}, \mathrm{C}_{5^{\prime}}\right), 67.39-67.36\left(\mathrm{~d}, J=5.2 \mathrm{~Hz}, \mathrm{C}_{5^{\prime}}\right), 61.13,32.43 \mathrm{ppm} .{ }^{31} \mathrm{P}$ NMR $(202.4$ $\mathrm{MHz}, \mathrm{D}_{2} \mathrm{O}$, external ref. $\left.\mathrm{H}_{3} \mathrm{PO}_{4}, 0.0 \mathrm{ppm}\right) \delta-10.38(\mathrm{dd}, J=19.4,5.8 \mathrm{~Hz}),-21.93$ $(\mathrm{t}, J=19.4 \mathrm{~Hz}) \mathrm{ppm}$. MS $\left(\mathrm{ESI}^{-}\right) \mathrm{m} / z(\%): 769(100), 791(20,+\mathrm{Na}), 813(5,+2 \mathrm{Na})$. HRMS (ESI) $\mathrm{m} / z$ : $\left[\mathrm{M}^{-}\right]\left(\mathrm{C}_{21} \mathrm{H}_{28} \mathrm{O}_{16} \mathrm{~N}_{10} \mathrm{P}_{3}\right)$ calc.: 769.09031, found: 769.08968.

\section{LC-MS data collection and analysis. LC-MS was performed using a Waters} Acquity UPLC SYNAPT G2 instrument with an Acquity UPLC BEH Amide column $(1.7 \mu \mathrm{m}, 2.1 \mathrm{~mm} \times 150 \mathrm{~mm}$, Waters). The mobile phase A consisted of $10 \mathrm{mM}$ ammonium acetate, $\mathrm{pH} 9$, and the mobile phase $\mathrm{B}$ of $100 \%$ acetonitrile. The flow rate was kept at $0.25 \mathrm{~mL} / \mathrm{min}$ and the mobile phase composition gradient was as follows: $80 \%$ B for 2 min; linear decrease to $68.7 \%$ B over 13 min; linear decrease to $5 \%$ B over $3 \mathrm{~min}$; maintaining $5 \%$ B for $2 \mathrm{~min}$; returning linearly to $80 \%$ B over $2 \mathrm{~min}$. For the analysis, electrospray ionization (ESI) was used with a capillary voltage of $1.80 \mathrm{kV}$, a sampling cone voltage of $20.0 \mathrm{~V}$, and an extraction cone voltage of $4.0 \mathrm{~V}$. The source temperature was $120^{\circ} \mathrm{C}$ and the desolvation temperature $550^{\circ} \mathrm{C}$, the cone gas flow rate was $50 \mathrm{~L} / \mathrm{h}$ and the desolvation gas flow rate $250 \mathrm{~L} / \mathrm{h}$. The detector was operated in negative ion mode. For each sample, $8 \mu \mathrm{L}$ of the dissolved material was injected.

Triplicates of Nuclease P1-digested RNA samples were used to identify $\mathrm{Np}_{n} \mathrm{Ns}$. Ions with $<50$ counts were not considered for further analysis. MassLynx software was used for data analysis and quantification of the relative abundance of dimethyl-Gp $\mathrm{F}_{4} \mathrm{G}$

MS $^{3}$ fragmentation analysis. The fragmentations studies were performed using SCIEX QTRAP 6500+ instrument with an Acquity UPLC BEH Amide column $(1.7 \mu \mathrm{m}, 2.1 \mathrm{~mm} \times 150 \mathrm{~mm}$, Waters). Mobile phase A was $10 \mathrm{mM}$ ammonium acetate $\mathrm{pH} 9$, and mobile phase $\mathrm{B}$ was $100 \%$ acetonitrile.

$A p_{3} A$ : For the determination of $\mathrm{Ap}_{3} \mathrm{~A}$ structure the flow rate was a constant $0.25 \mathrm{~mL} / \mathrm{min}$ and the mobile phase composition was as follows: $80 \%$ B for $2 \mathrm{~min}$; linear decrease over $3 \mathrm{~min}$ to $50 \% \mathrm{~B}$; and maintain at $50 \% \mathrm{~B}$ for $1 \mathrm{~min}$ before returning linearly to $80 \%$ B over 2 min. ESI was used with curtain gas of 35 (arbitrary units), Ionspray voltage of $4.5 \mathrm{kV}$. The ion source gas was 50 (arbitrary units), and the drying gas temperature was $400{ }^{\circ} \mathrm{C}$. The declustering potential was $-200 \mathrm{~V}$, the entrance potential $-10 \mathrm{~V}$, collision energy $-46 \mathrm{~V}$, excitation energy $0.1 \mathrm{~V}$. The detector was operated in negative ion mode. For the confirmation of $\mathrm{Ap}_{3} \mathrm{~A}$ structure, the first precursor ion was $[\mathrm{M}-\mathrm{H}]^{-}$at $m / z 754.96$ and as second ion the ATP fragment was selected $[\mathrm{M}-\mathrm{H}]^{-}$at $m / z$ 487.8. For each sample, $8 \mu \mathrm{L}$ of the dissolved material was injected.

$m A p_{3} A$ : For the determination of $\mathrm{mAp} 3 \mathrm{~A}$ structure the flow rate was a constant $0.20 \mathrm{~mL} / \mathrm{min}$ and the mobile phase composition was as follows: $80 \% \mathrm{~B}$ for $2 \mathrm{~min}$; linear decrease over $12 \mathrm{~min}$ to $50 \% \mathrm{~B}$; and maintain at $50 \%$ B for $1 \mathrm{~min}$ before returning linearly to $80 \%$ B over 2 min. ESI was used with curtain gas of 20 (arbitrary units), ionspray voltage of $4.5 \mathrm{kV}$. The ion source gas was 50 (arbitrary units), and the drying gas temperature was $400^{\circ} \mathrm{C}$. The declustering potential was $-300 \mathrm{~V}$, the entrance potential $-10 \mathrm{~V}$, collision energy $-54 \mathrm{~V}$, and excitation energy $0.1 \mathrm{~V}$. The detector was operated in negative ion mode. For the identification of $\mathrm{mAp}_{3} \mathrm{~A}$ structure, the first precursor ion was $[\mathrm{M}-\mathrm{H}]^{-}$at $m / z$ 768.908 and as second ion the dehydrated mAMP fragment was selected $[\mathrm{M}-\mathrm{H}]^{-}$ at $m / z$ 341.8. For each sample, $8 \mu \mathrm{L}$ of the dissolved material was injected.

Quantification. A total of $2 \mathrm{mg}$ of sRNA from STA was divided in four aliquots. After digestion with $\mathrm{NuP1}$, each aliquot was spiked with increasing concentration of $\mathrm{Np}_{n} \mathrm{Ns}\left(\mathrm{Ap}_{3} \mathrm{~A}, \mathrm{Ap}_{3} \mathrm{G}, \mathrm{m}^{7} \mathrm{Gp}_{4} \mathrm{G}\right.$, and $\left.A p_{5} \mathrm{~A}\right), \mathrm{NAD}$, and CoA. After LC-MS analysis of all the aliquots the area under the peak was calculated and plotted against the concentration. The experimental points were fitted with a liner regression and the intercept with $X$-axis represent the concentration of the cap in the sample. The quantification was repeated three times and the final value was obtained from the average of the three measurement with relative SD.

MD simulations. All models were based on a crystal structure of E. coli RppH in complex with modified ppcpAG $5^{\prime}$-capped dinucleotide (PDB ID 4S2Y). We modified the adenine to guanine and extended the $5^{\prime}$-nucleotide triphosphate into $\mathrm{Gp}_{4} \mathrm{G}$ or the methylated $\mathrm{m}^{7} \mathrm{Gp}_{4} \mathrm{Gm}$. Hydrogens were added so that the amino acids were present in the standard protonation state at $\mathrm{pH}$ 7. Three catalytic magnesium ions were kept in place. The complex was solvated in an 83 $\times 68 \times 71 \AA$ A box of water molecules. Some water molecules were replaced by sodium and chlorine ions to neutralize the complex charge and mimic the cellular ionic strength $(0.15 \mathrm{M})$. The MD simulations were performed using the NAMD software ${ }^{41}$ and AMBER force field with ff14SB (ref. ${ }^{42}$ ) parameters for the protein, OL3 (ref. ${ }^{43}$ ) parameters for RNA, the SPC/E model of water ${ }^{44}$, and corresponding parameters for monovalent ions ${ }^{45}$ and magnesium ${ }^{46}$. Parameters for non-canonical RNA caps were constructed using existing RNA parameters and available parameters for polyphosphates ${ }^{47}$. Partial atomic charges were fitted based on quantum-chemical HF/6-31 G* calculations using Gaussian 09 (ref. ${ }^{48}$ ) using the RESP procedure AmberTools ${ }^{49}$. We used periodic boundary conditions in the MD simulations to emulate a bulk solvent. An isobaric-isothermal ensemble (NPT) scheme with Langevain temperature and pressure control was applied. The following equilibration protocol was used: (1) 1000 steps of conjugate gradient minimization with restraints on heavy atoms of the protein and RNA, (2) heating from 0 to $310 \mathrm{~K}$ followed by $10 \mathrm{ps}$ of $\mathrm{MD}$ with above restraints, (3) 1000 steps of minimization without restraints, and (4) heating from 0 to 310 $\mathrm{K}$ followed by $100 \mathrm{ps}$ of unrestrained equilibration. We used $1 \mathrm{fs} \mathrm{MD}$ integration steps for the equilibration phase and $2 \mathrm{fs}$ for the $200 \mathrm{~ns}$ production phase. The final snapshots were visualized using $\mathrm{PyMol}^{50}$.

Reporting summary. Further information on research design is available in the Nature Research Reporting Summary linked to this article.

\section{Data availability}

A reporting summary for this Article is available as a Supplementary Information file. Source data used in this work are publicly available at https://figshare.com/articles/ Source_Data_Hudecek_Benoni_Cahova_2019_xlsx/11637132. All other data are available from the authors upon reasonable request. 
Received: 2 April 2019; Accepted: 7 February 2020;

Published online: 26 February 2020

\section{References}

1. Cahová, H., Winz, M.-L., Höfer, K., Nübel, G. \& Jäschke, A. NAD captureSeq indicates NAD as a bacterial cap for a subset of regulatory RNAs. Nature 519, 374 (2014).

2. Chen, Y. G., Kowtoniuk, W. E., Agarwal, I., Shen, Y. \& Liu, D. R. LC/MS analysis of cellular RNA reveals NAD-linked RNA. Nat. Chem. Biol. 5, 879 (2009).

3. Kowtoniuk, W. E., Shen, Y., Heemstra, J. M., Agarwal, I. \& Liu, D. R. A chemical screen for biological small molecule-RNA conjugates reveals CoAlinked RNA. Proc. Natl Acad. Sci. 106, 7768-7773 (2009).

4. McLennan, A. G. Substrate ambiguity among the nudix hydrolases: biologically significant, evolutionary remnant, or both? Cell. Mol. Life Sci. 70, 373-385 (2013).

5. Höfer, K. et al. Structure and function of the bacterial decapping enzyme NudC. Nat. Chem. Biol. 12, 730 (2016).

6. Zhang, D. et al. Structural basis of prokaryotic NAD-RNA decapping by NudC. Cell Res. 26, 1062 (2016).

7. Deana, A., Celesnik, H. \& Belasco, J. G. The bacterial enzyme RppH triggers messenger RNA degradation by $5^{\prime}$ pyrophosphate removal. Nature 451, 355 (2008).

8. Luciano, D. J., Vasilyev, N., Richards, J., Serganov, A. \& Belasco, J. G. A novel RNA phosphorylation state enables $5^{\prime}$ end-dependent degradation in Escherichia coli. Mol. Cell 67, 44-54. e46 (2017).

9. Grudzien-Nogalska, E. \& Kiledjian, M. New insights into decapping enzymes and selective mRNA decay. Wiley Interdiscip. Rev. RNA 8, e1379 (2017).

10. Song, M.-G., Li, Y. \& Kiledjian, M. Multiple mRNA decapping enzymes in mammalian cells. Mol. Cell 40, 423-432 (2010).

11. McLennan, A. G. Ap4a and Other Dinucleoside Polyphosphates (Taylor \& Francis, 1992).

12. McLennan, A. G. The Nudix hydrolase superfamily. Cell. Mol. Life Sci. CMLS 63, 123-143 (2006)

13. Zamecnik, P. G., Stephenson, M. L., Janeway, C. M. \& Randerath, K. Enzymatic synthesis of diadenosine tetraphosphate and diadenosine triphosphate with a purified lysyl-sRNA synthetase. Biochem. Biophys. Res. Commun. 24, 91-97 (1966).

14. McLennan, A. G. Dinucleoside polyphosphates-friend or foe? Pharmacol. Therapeutics 87, 73-89 (2000).

15. Despotović, D. et al. Diadenosine tetraphosphate (Ap4A) - an E. coli alarmone or a damage metabolite? FEBS J. 284, 2194-2215 (2017).

16. VanBogelen, R. A., Kelley, P. M. \& Neidhardt, F. C. Differential induction of heat shock, SOS, and oxidation stress regulons and accumulation of nucleotides in Escherichia coli. J. Bacteriol. 169, 26-32 (1987).

17. Guranowski, A. Studies on dinucleoside polyphosphates some intriguing biochemical, physiological, and medical aspects. J. Clin. Biochem. Nutr. 28, 177-189 (2000).

18. Götz, K. H. et al. Formation of the alarmones diadenosine triphosphate and tetraphosphate by ubiquitin- and ubiquitin-like-activating enzymes. Cell Chem. Biol. 26, 1535-1543. e1535 (2019)

19. Walters, R. W. et al. Identification of NAD+ capped mRNAs in Saccharomyces cerevisiae. Proc. Natl Acad. Sci. USA 114, 480-485 (2017).

20. Jiao, X. et al. $5^{\prime}$ End nicotinamide adenine dinucleotide cap in human cells promotes rna decay through dxo-mediated deNADding. Cell 168, 1015-1027. e1010 (2017).

21. Adams, J. M. \& Cory, S. Modified nucleosides and bizarre $5^{\prime}$-termini in mouse myeloma mRNA. Nature 255, 28-33 (1975).

22. Bird, J. G. et al. The mechanism of RNA $5^{\prime}$ capping with NAD+, NADH and desphospho-CoA. Nature 535, 444 (2016).

23. Huang, F. Efficient incorporation of CoA, NAD and FAD into RNA by in vitro transcription. Nucleic Acids Res. 31, e8-e8 (2003).

24. Durniak, K. J., Bailey, S. \& Steitz, T. A. The structure of a transcribing T7 RNA polymerase in transition from initiation to elongation. Science 322, 553-557 (2008).

25. JEMIELITY, J. et al. Novel "anti-reverse" cap analogs with superior translational properties. RNA 9, 1108-1122 (2003).

26. Barvík, I., Rejman, D., Šanderová, H., Panova, N. \& Krásný, L. Non-canonical transcription initiation: the expanding universe of transcription initiating substrates. FEMS Microbiol. Rev. 41, 131-138 (2016).

27. Vvedenskaya, I. O. et al. CapZyme-seq comprehensively defines promotersequence determinants for RNA $5^{\prime}$ capping with NAD+. Mol. Cell 70, 553-564. e559 (2018).

28. Lee, P. C., Bochner, B. R. \& Ames, B. N. AppppA, heat-shock stress, and cell oxidation. Proc. Natl Acad. Sci. 80, 7496-7500 (1983).
29. Bessman, M. J. et al. The gene, ygdP, associated with the invasiveness of Escherichia coli K1, designates a nudix hydrolase (Orf 176) active on Adenosine (5') pentaphospho (5') adenosine. J. Biol. Chem. 276, 37834-37838 (2001).

30. Guranowski, A., Jakubowski, H. \& Holler, E. Catabolism of diadenosine 5, 5"' $\mathrm{P} 1, \mathrm{P} 4$-tetraphosphate in procaryotes. Purification and properties of diadenosine 5',5"'-P1,P4-tetraphosphate (symmetrical) pyrophosphohydrolase from Escherichia coli K12. J. Biol. Chem. 258, 14784-14789 (1983).

31. Foley, P. L., Hsieh, P.-k., Luciano, D. J. \& Belasco, J. G. Specificity and evolutionary conservation of the Escherichia coli RNA pyrophosphohydrolase RppH. J. Biol. Chem. 290, 9478-9486 (2015).

32. Kröger, C. et al. An infection-relevant transcriptomic compendium for $<$ em $>$ Salmonella enterica $</$ em $>$ Serovar Typhimurium. Cell Host Microbe 14, 683-695 (2013).

33. Mauer, J. et al. Reversible methylation of m6Am in the $5^{\prime}$ cap controls mRNA stability. Nature 541, 371 (2016).

34. Luciano, D. J., Levenson-Palmer, R. \& Belasco, J. G. Stresses that raise Np4A levels induce protective nucleoside tetraphosphate capping of bacterial RNA. Mol. Cell 75, 957-966. e958 (2019).

35. Rasband, W. S. ImageJ. U. S. National Institutes of Health (Bethesda, Maryland, USA, 1997-2018).

36. Qi, Y. \& Hulett, F. M. PhoP P and RNA polymerase $\sigma$ A holoenzyme are sufficient for transcription of Pho regulon promoters in Bacillus subtilis: $\mathrm{PhoP} \sim \mathrm{P}$ activator sites within the coding region stimulate transcription in vitro. Mol. Microbiol. 28, 1187-1197 (1998).

37. Oslovsky, V. E., Drenichev, M. S. \& Mikhailov, S. N. Regioselective 1-Nalkylation and rearrangement of adenosine derivatives. Nucleosides, Nucleotides Nucleic Acids 34, 475-499 (2015).

38. Jones, J. W. \& Robins, R. K. Purine nucleosides. III. Methylation studies of certain naturally occurring purine nucleosides. J. Am. Chem. Soc. 85, 193-201 (1963).

39. Moreau, C. et al. Aberrant cyclization affords a C-6 modified cyclic adenosine $5^{\prime}$-diphosphoribose analogue with biological activity in Jurkat T cells. J. Med. Chem. 55, 1478-1489 (2012).

40. Graham, S. M., Macaya, D. J., Sengupta, R. N. \& Turner, K. B. cADPR analogues: effect of an adenosine 2'- or 3'-methoxy group on conformation. Org. Lett. 6, 233-236 (2004).

41. Goh, G. B., Hodas, N. O. \& Vishnu, A. Deep learning for computational chemistry. J. Comput. Chem. 38, 1291-1307 (2017).

42. Alarcos, N., Cohen, B., Ziółek, M. \& Douhal, A. Photochemistry and photophysics in silica-based materials: ultrafast and single molecule spectroscopy observation. Chem. Rev. 117, 13639-13720 (2017).

43. Palermo, G., Miao, Y., Walker, R. C., Jinek, M. \& McCammon, J. A. Striking plasticity of CRISPR-Cas9 and key role of non-target DNA, as revealed by molecular simulations. ACS Cent. Sci. 2, 756-763 (2016).

44. Berendsen, H. J. C., Grigera, J. R. \& Straatsma, T. P. The missing term in effective pair potentials. J. Phys. Chem. 91, 6269-6271 (1987).

45. Wang, J. et al. Twin defect derived growth of atomically thin MoS2 dendrites. ACS Nano 12, 635-643 (2018).

46. Yang, Q. et al. Donor engineering for NIR-II molecular fluorophores with enhanced fluorescent performance. J. Am. Chem. Soc. 140, 1715-1724 (2018).

47. Shupanov, R., Chertovich, A. \& Kos, P. Micellar polymerization: computer simulations by dissipative particle dynamics. J. Comput. Chem. 39, 1275-1284 (2018).

48. Gaussian 09, Revision A.02 (2016).

49. A. Case, et al. AMBER (University of California, San Francisco, 2016).

50. DeLano, W. L. Pymol: an open-source molecular graphics tool. CCP4 Newsl. Protein Crystallogr. 40, 82-92 (2002).

\section{Acknowledgements}

Jiři Potužník, Maria-Bianca Mititelu, Victoria Fincke, Carlos Murillo Almuzara and other members of Cahova lab for their help and discussion. We acknowledge funding from the Ministry of Education, Youth, and Sports (Czech Republic), program ERC CZ (LL1603), and Czech Science Foundation (17-03419S; to LK).

\section{Author contributions}

O.H., R.B., and H.C. designed the experiments and coordinated the project. O.H. and R.B. performed the experiments. P.E.R-.G. synthesized $\mathrm{mAp}_{3}$ A. H.Šs. prepared ApaH. M.C. performed the MD study. M.H. and J. C. consulted the LC-MS results. J.C., L.R., L.K., and H.C. supervised the work. O.H., R.B., M.C., and H.C. wrote the paper

\section{Competing interests}

The authors declare no competing interests. 


\section{Additional information}

Supplementary information is available for this paper at https://doi.org/10.1038/s41467020-14896-8

Correspondence and requests for materials should be addressed to H.C.

Peer review information Nature Communications thanks the anonymous reviewers for their contribution to the peer review of this work. Peer reviewer reports are available.

Reprints and permission information is available at http://www.nature.com/reprints

Publisher's note Springer Nature remains neutral with regard to jurisdictional claims in published maps and institutional affiliations. (c) (i) Open Access This article is licensed under a Creative Commons Attribution 4.0 International License, which permits use, sharing, adaptation, distribution and reproduction in any medium or format, as long as you give appropriate credit to the original author(s) and the source, provide a link to the Creative Commons license, and indicate if changes were made. The images or other third party material in this article are included in the article's Creative Commons license, unless indicated otherwise in a credit line to the material. If material is not included in the article's Creative Commons license and your intended use is not permitted by statutory regulation or exceeds the permitted use, you will need to obtain permission directly from the copyright holder. To view a copy of this license, visit http://creativecommons.org/ licenses/by/4.0/.

(C) The Author(s) 2020 